\title{
MAATALOUSRAKENNUSTEN MÄÄRÄ JA ARVO SEKÄ RAKENNUSTEN KAPASITEETIN HYVÄKSIKÄYTTO ERÄIDEN POHJOIS-KARJALAN KUNTIEN ALUEELLA VUONNA 1960
}

\author{
VILJO RYYNÄNEN \\ Helsingin yliopiston maanviljelystalouden laitos
}

Saapunut 18. 12. 1964

Maatalousrakennusten tarve riippuu huomattavalta osalta viljelmällä harjoitettavasta tuotantotoiminnasta. Tuotannon suuntautuessa yksinomaan tai pääasiallisesti myytävien kasvien tuottamiseen rakennusten tarve saattaa olla sangen pieni. Näin etenkin silloin, kun tuotteet myydään suoraan pellolta ostavan liikkeen varastoihin. Tällöin tarvitaan varastotilaa vain siemeniä, lannoitteita ja koneita varten. Tuotannon keskittyessä viljelmällä varastoitavien ja myöhemmin sieltä myytävien kasvien tuottamiseen, varastojen tarve lisääntyy. Kun kasvinviljelytuotteita ryhdytään viljelmällä jalostamaan esim. kotieläintuotteiksi, tarvitaan rakennustilaa myös jalostustuotantoa varten. Rakennustilan tarve vaihtelee tällöin tuotannon laajuuden mukaan. Maamme viljelmillä jalostustoiminta on lähes yksinomaan kasvituotteiden jalostusta kotieläintuotteiksi. Siksi jalostustuotantoa varten tarvittavat rakennukset ovat pääasiallisesti kotieläinrakennuksia näihin liittyvine välttämättömine aputiloineen.

Rakennukset suunnitellaan vallitsevaa tai tavoitteeksi asetettua peltoalaa, tuotantosuuntaa ja intenssiteettiastetta varten. Rakennusten kestoaika on yleensä pitkä. Niitten kestoaikana voi viljelmän peltoala, tuotantosuunta tai intenssiteettiaste merkittävästi muuttua. Viimeisen kahden vuosikymmenen aikana on maataloudessa tapahtunut muutoksia, jotka ovat muuttaneet oleellisesti viljelmien rakennustarvetta. Maatalouskoneiden lisääntyminen ja uudentyyppisten koneiden hankinta on lisännyt kalustojen ja lämpimien, kaluston huoltoon ja säilytykseen soveltuvien rakennusten tarvetta.

Maataloustuotteiden jalostustoiminnan siirtyminen teollisuuden tehtäväksi on tehnyt tarpeettomaksi monet viljelmällä aiemmin tähän tarkoitukseen käytetyt rakennustilat. Niinpä keskikokoisten ja suurten maatilojen maidonkäsittelyhuoneet, 
voin- ja juustonvalmistustilat, teurastushuoneet ja leivintuvat ovat nyt tarpeettomia tai niitä käytetään muihin tarkoituksiin.

Leikkuupuinti ja viljan siirto joko suoraan pellolta viljaa ostavan liikkeen kuivaamoon tai oman kuivaamon kautta liikkeen varastoon on muttanut varastotilojen tarvetta viljelmillä. Vielä 1940-luvun lopulla ja 1950-luvun alussa vilja puitiin pääasiallisesti paikoilleen asennetuilla puimakoneilla. Näihin vuosiin saakka rakennettiin viljelmille kylmää varastotilaa niin runsaasti, että puinti voitiin suorittaa sisällä. Useissa tapauksissa myös oljet varastoitiin sisälle. Nyt puidaan viljasta yli $50 \%$ leikkuupuimurilla. Osa olkisadosta tai koko olkisato kynnetään maahan. Eräillä viljelmillä varastoitavat oljet paalataan ennen varastointia. Olkivarastojen tarve on supistunut hyvin huomattavasti. Myös viljavarastojen tarve viljelmillä vähenee, kun vilja myydään heti sadonkorjuun jälkeen.

Keskikokoisilla ja suurilla maatiloilla jouduttiin pitämään $15-20$ vuotta sitten useita palkattuja työntekijöitä. Kun ihmistyövoiman tarve on supistunut töiden koneellistuessa, on palkattua työvoimaa voitu vähentää. Palkattujen, maatilalla asuvien työntekijäin luku oli maatalouslaskennan mukaan alla mainittuina vuosina seuraava:

$\begin{array}{cc}\text { Miehiä } & \text { Naisia } \\ 195030565 & 31765 \\ 195918174 & 18916\end{array}$

Vuoden 1950:n laskenta koskee maatiloilla asuvia palkattuja työntekijöitä ja vuoden 1959:n laskenta viljelmillä työskenteleviä vieraita henkilöitä. Kun nyt tarvitaan palkattuja työntekijöitä vain noin $50 \%$ vuoden 1950:n määrästä, on maatiloille jäänyt tyhjiä asuntoja tai niitä on jouduttu muuttamaan uusiin tarkoituksiin soveltuviksi.

Kotieläinten luku 100 peltohehtaaria kohti on osoittanut alenevaa suuntaa. Seuraavassa asetelmassa on esitetty nautayksiköiden luku 100 peltohehtaaria kohti Etelä- ja Sisä-Suomen kirjanpitotilojen I:ssä, II:ssa ja III:ssa suuruusluokassa.

\begin{tabular}{lrrrrrrr} 
& \multicolumn{3}{c}{ Etelä-Suomi } & \multicolumn{3}{c}{ Sisä-Suomi } \\
Vuosi & \multicolumn{1}{c}{ I } & \multicolumn{1}{c}{ II } & III & I & II & III \\
$1939 / 40$ & 116 & 94 & 79 & 120 & 95 & 87 \\
$1951 / 52$ & 96 & 79 & 64 & 111 & 92 & 74 \\
$1960 / 61$ & 88 & 65 & 47 & 88 & 70 & 56
\end{tabular}

Kotieläinten määrä kirjanpitotiloilla on supistunut sangen voimakkaasti. Nautayksiköiden luku on nyt I:ssä suuruusluokassa noin 1/4 ja II:ssa sekä III:ssa suuruusluokassa noin $1 / 3$ pienempi kuin 20 vuotta sitten. Hevosten ja lampaiden luku on vänhentynyt eniten, mutta myös lehmiä on nyt vähemmän kuin 20 vuotta sitten.

On varsin todennäköistä, että osa kotieläinrakennuksista on nyt käyttämättä. Kotieläinrakennuksien kestoikä on yleensä pitkä. Tällaisten rakennusten muuttaminen siten, että niiden kapasiteetti tulisi kokonaan käytettyä hyväksi tuotantoa 
supistettaessa on poikkeuksia lukuunottamatta työlästä ja kallista. Siksi rakennusta käytetään usein sellaisenaan tuotannon muutoksista huolimatta.

Maatalouden tuotantokustannuksista rakennuskustannus on ihmistyökustannusta lukuunottamatta keskimäärin suurin. ANNILAN (1, s. 133) mukaan korkokannan ollessa $6 \%$ maatalouden rakennusten vuotuiskustannus olisi noin $10 \%$ rakennusten nykyarvosta. HENRIKSSON (5, s. 24) laskee kotieläinrakennusten vuotuiskustannukseksi $5 \%$ korkokannan vallitessa n. $7.5 \%$ rakennusten uudisarvosta edellyttäen, että rakennukset kestävät 50 vuotta. Annilan mukaan olisi vuotuinen rakennuskustannus I suuruusluokan kirjanpitoviljelmillä vuonna 1960 ollut noin $250 \mathrm{mk} / \mathrm{ha}$, II suuruusluokan viljelmillä $170 \mathrm{mk} / \mathrm{ha}$ ja III suuruusluokan viljelmillä noin $130 \mathrm{mk} / \mathrm{ha}$.

Kustannusten supistamiseksi viljelijä joutuu harkitsemaan, minkä verran maatila todella tarvitsee rakennuksia ja minkälaisiksi ne olisi tehtävä, että vuotuiskustannukset eivät kohoaisi suhteettoman korkeiksi. Tässä tutkimuksessa pyritään selvittämään, kuinka suuret eri kokoisten maatilojen rakennukset tutkimuksen kohteena olevilla viljelmillä olivat tutkimusaineistoa kerättäessä ja paljonko pääomaa oli sidottu niihin sekä, kuinka suuressa määrin näiden maatilojen talousrakennusten kapasiteettia oli tutkimushetkellä käytetty hyväksi.

\section{Tutkimusaineisto}

Tutkimuksen suorittaja kokosi vuosina 1960 ja 1961 aineistoa tutkimusta varten, jossa on pyrkimyksenä selvittää maatalousmaan pakkoluovutuksen maan luovuttajalle aiheuttamia menetyksiä. Mainittua tutkimusta varten kirjoittaja tarvitsi tietoja mm. maata luovuttaneiden viljelmien rakennusten arvosta. Kirjoittaja kävi jokaisella tutkitulla viljelmällä ja hankki tiedot tärkeimmistä rakennusten arvoon vaikuttavista seikoista. Kun kerätystä, rakennuksia koskevista aineistosta edellämainitussa tutkimuksessa ei julkaista kuin pääpiirteitä, on tässä tutkimuksessa tarkoitus aineiston sallimissa puitteissa selvitellä tarkemmin johdannossa mainittuja seikkoja.

Taulukko 1. Maankäyttölajien jakaantuminen tutkimusalueella.

Table 1. The distribution of land use in the investigation area.

Pitäjä

Parish
Maankäyttölajien osuus maa-alasta \% Percentage of land used as

peltoa
arable land
meadow and pasture

\begin{tabular}{|c|c|c|c|c|}
\hline Kesälahti . . & 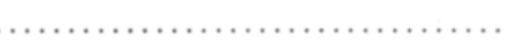 & 9.2 & 1.4 & 89.4 \\
\hline Kitee ...... & 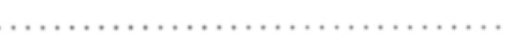 & 13.3 & 1.7 & 85.0 \\
\hline Liperi .... & 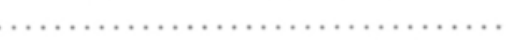 & 15.4 & 1.9 & 82.7 \\
\hline Pyhäselkä & 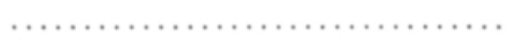 & 18.1 & 3.2 & 78.7 \\
\hline Tohmajärvi & 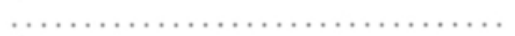 & 11.6 & 1.6 & 86.8 \\
\hline
\end{tabular}


Tutkimusaineisto on kerätty Pohjois-Karjalan eteläisimpien pitäjien alueelta. Tutkitut viljelmät jakaantuvat eri pitäjien kesken seuraavasti:

$\begin{array}{lll}\text { Kesälahti } & 10 & \text { Pyhäselkä } 27 \\ \text { Kitee } & 12 & \text { Tohmajärvi } 16 \\ \text { Liperi } & 64 & \end{array}$

Taulukossa 1 on esitetty eräitä piirteitä edellämainittujen pitäjien maankäyttölajien jakaantumisesta Pohjois-Karjalan komitean mietinnön (20, s. 3) ja vuoden 1959:n yleisen maatalouslaskennan (29) mukaan.

Taulukosta 2 käy ilmi viljelmien keskikoko tutkimusalueella. Taulukkoon on otettu mukaan myös Pohjois-Karjalan maanviljelysseuran alueen, johon tutkimusalue osana kuuluu, viljelmien keskikoko.

Taulukko 2. Viljelmien keskikoko ha tutkituilla viljelmillä sekä tutkimus- ja Pohjois-Karjalan maanviljelysseuran alueella.

Table 2. Mean farm size, hectares, of the farms studied, in the investigation area and the area of the agricultural society of North Karelia.

\begin{tabular}{|c|c|c|c|}
\hline & $\begin{array}{l}\text { Peltoa }^{1} \\
\text { Field }^{1}\end{array}$ & $\begin{array}{l}\text { Niittyä ja laidunta } \\
\text { Meadow and pasture }\end{array}$ & $\begin{array}{c}\text { Kasvavaa } \\
\text { metsää } \\
\text { Growing forest }\end{array}$ \\
\hline $\begin{array}{l}\text { Tutkitut viljelmät } \ldots \ldots \ldots \ldots \ldots \ldots \ldots \ldots \ldots \ldots \\
\text { Farms studied }\end{array}$ & 10.55 & $1.52^{1}$ & $28.58^{1}$ \\
\hline $\begin{array}{l}\text { Tutkimusalueen kaikki viljelmät } \ldots \ldots \ldots \ldots \ldots \\
\text { All farms in investigation area }\end{array}$ & 7.45 & $0.80^{2}$ & $23.24^{2}$ \\
\hline $\begin{array}{l}\text { Pohj.-Karjalan mv. seura } \ldots \ldots \ldots \ldots \ldots \ldots \ldots \\
\text { Agricultural society of North Karelia }\end{array}$ & 6.43 & $0.99^{2}$ & $31.32^{2}$ \\
\hline $\begin{array}{l}{ }^{1} 2.00 \text { ha ja yli } \\
2.00 \text { hectares and over } \\
{ }^{2} \text { Kaikki viljelmät } \\
\text { All farms }\end{array}$ & . & & \\
\hline
\end{tabular}

Tutkittujen viljelmien peltoala on 3.10 ha suurempi kuin saman alueen kaikkien viljelmien keskikoko. Pääasiallisesti tulos johtunee siitä, että uudet tiet on sijoitettu kulkemaan parhaimpien viljelyalueiden kautta, joilla viljelmien keskikoko näyttää olevan suurempi kuin syrjäseuduilla. Teiden sijoitus taas lienee seuraus siitä, että asutustaajamat, joita tiet yhdistävät, ovat sijoittuneet pääasiallisesti juuri sinne, missä maaperä on ollut kelvollisinta viljelytarkoituksiin.

Peltoalan mukaan jakaantuivat tutkitut viljelmät eri suuruusluokkiin alla olevan asetelman esittämällä tavalla. Suuruusluokkajaoitus on sama kuin maatalouden kannattavuustutkimuksessa.

\begin{tabular}{rrcc} 
Suuruusluokka & Viljelmien luku & \multicolumn{2}{c}{$\begin{array}{c}\text { ruusluokassa, ha } \\
\text { muunn. peltoa }\end{array}$} \\
I $2.00-9.99$ & 71 & 5.67 & 5.95 \\
II $10.00-24.99$ & 50 & 13.02 & 13.72 \\
III $25.00-49.99$ & 8 & 35.48 & 38.32
\end{tabular}


Yhden viljelmän muunnettu peltoala oli 52.29 ha, mutta tämä on luettu III suuruusluokkaan, koska muita IV:n suuruusluokan viljelmiä ei kuulunut aineistoon.

Tutkimuksessa ovat mukana ne viljelmät, joista on pakkolunastettu maatalousmaata vuosina 1956-1961 tiemaaksi uusien valtateiden rakentamista varten edellä mainitulla alueella. Pyrkimyksenä oli ottaa mukaan kaikki viljelmät, joilla oli peltoa ennen maatalousmaan luovuttamista 2.00 ha tai enemmän. Asetetut ehdot täyttäviä viljelmiä on täytynyt jättää pois seitsemän, koska kirjoittaja ei voinut saada kaikkia tarvittavia tietoja näiltä viljelmiltä. Tutkimusaineisto on koottu sen jälkeen, kun maan luovutus oli tapahtunut.

Kun tutkimukseen kuuluvat viljelmät on valittu ylläesitettyä menettelyä käyttäen, aineistoa ei voida pitää edustavana näytteenä kyseisen alueen viljelmistä. Taulukosta 2 voidaan havaita, että tutkitut viljelmät ovat huomattavasti suurempia kuin tutkitun alueen tai Pohjois-Karjalan maanviljelysseuran alueen viljelmät. Koska aineisto ei ole näyte, ei ole oikein analysoida sitä näytteen tavoin. Aineistosta ei voida tehdä myöskään johtopäätöksiä kuten näytteen perusteella tehdään. Seuraavassa esitetään tutkimusaineistoa koskevia, paikallista keskittymistä tai hajaantumista osoittavia tunnuslukuja sekä muutamia tutkimusaineistoa kuvaavia funktioita.

\section{Käytetyt arviointimenetelmät}

Rakennusten mittaus on suoritettu seuraavaa menettelyä käyttäen:

Lämpimät rakennukset: Pinta-ala on laskettu rakennusten ulkomittojen mukaan. Korkeus on mitattu kellarin tai maavaraisen lattian yläpinnasta tai, jos kellaria ei ole ollut, alapohjan alapinnasta yläpohjan yläpintaan tai, jos vesikatto liittyi välittömästi välipohjaan, vesikaton yläpintaan.

Kylmät rakennukset kuten rehuladot, varastot, halkovajat ja muut näiden kaltaiset: Pinta-ala on laskettu kuten edellä. Korkeus on mitattu seinän alareunasta tasakertaan. Taitekattoisissa rakennuksissa on myös tasakerrasta taitteen yläreunaan ulottuva tila otettu huomioon. Jos lämpimien rakennusten ullakolla oli kylmää käyttötilaa, on sen tilavuus laskettu kuten kylmien rakennusten kohdalla on esitetty. Rakennusten mitat on otettu metreinä yhden desimaalin tarkkuudella.

Tutkimuksen suorittaja arvioi viljelmillä käydessään kunkin rakennuksen kunnon. Se on ilmastu kuntoisuuslukua $(0-10)$ käyttäen. Kuntoisuusluvulla on ilmaistu arvioitavan rakennuksen suhde $\operatorname{ArOLAN}(2$, s. 80) esittämään mnormaalirakennukseen"; vrt. Holmovist (7, s. 10). Tässä yhteydessä ei ole otettu huomioon ainoastaan rakennuksen teknillistä tasoa, vaan myös taloudellinen käyttöarvo siihen tarkoitukseen käytettynä, jota rakennus maatilalla palveli. Tämä on tarpeen erikoisesti vanhoja kivirakenteisia kotieläinsuojia ja pieniä latoja arvioitaessa. Rakennus voi teknillisesti täyttää normaalirakennukselle asetettavat vaatimukset, mutta taloudellisesti se saattaa olla epätarḳoituksenmukainen. Tämä menettelytapa tuo tosin arvioon sen suorittajan subjektiivisen näkemuksen arvioinnin kohteesta, mutta ottamatta rakennuksen teknillistä tasoa ja sen tarkoituksenmukaisuutta eräissä tapauksissa ei liene mahdollisuuksia saada esille edes likimääräistä rakennuksen taloudellista arvoa. 
Rakennusten jälleenhankinta-arvoa laskettaessa on käytetty AroLA:N (2, s. 89) esittämiä kuutiohintoja. Koska nämä on laadittu vuoden 1956 syksyn hintatason mukaan ja tutkimuksessa on haluttu saada esille rakennusten arvo vuonna 1960, on Arola:n esittämiä kuutiohintoja korjattu. Korjaus on suoritettu PellervoSEURAN markkinatutkimuslaitoksen laatiman rakennustarvike-indeksin mukaan. AROLA on esittänyt ohjehinnat keskinkertaista huonommalle, keskinkertaiselle ja hyvälle rakennukselle. Näitä vastaamaan on otettu kymmenasteikon kuntoisuus luvut 4, 7 ja 9. Muita lukuja vastaavat kuutiohinnat on interpoloitu Arola: ohjehintojen ja kuntoisuuslukujen suhteessa.

Rakennuksen yksikköhinta vaihtelee myös rakennuksen koon mukaan. Suuren rakennuksen hinta tilavuusyksikköä kohti on pienempi kuin pienen. Arola:N esittämiä indeksin mukaan korjattuja yksikköhintoja on käytetty $300 \mathrm{~m}^{3}$ asuinja kotieläinrakennuksia sekä kylmiä varastosuojia arvioitaessa. Rakennuksen tilavuuden muuttuessa on yksikköhintoja muutettu seuraavasti; vrt. SIPILÄ (22, s. 16) ja Gripenberg $(4$, s. 7$)$ :

$\begin{array}{llllcc}\text { Rakennus } & 100 \mathrm{~m}^{3} & 200 \mathrm{~m}^{3} & 300 \mathrm{~m}^{3} & 400 \mathrm{~m}^{3} & 500 \mathrm{~m}^{3} \\ \text { Asuinrakennus } & 120 & 110 & 100 & 95 & 90 \\ \text { Kotieläinrakennus } & 130 & 110 & 100 & 97 & 95 \\ \text { Puimala, lato } & 130 & 110 & 100 & 95 & 95\end{array}$

Eri rakennusten kestoaika rakennusten nykyarvoa laskettaessa on tässä tutkimuksessa oletettu enintään seuraavan pituiseksi. Rakennusten kestoaikaa arvioitaessa on käytetty apuna mm. MÄEn (17, s. 58-76) ja Holmovistin (7. s. 10) suorittamia rakennusten kestoaikaa koskevia tutkimuksia.

Asuinrakennukset
Saunat
Puiset kotieläinrakennukset
Kiviset
Ladot, puimalat, vajat
Aitat, viljavarastot
Riihet

Yllä esitettyjä kestoaikoja on käytetty sellaisenaan vain hyvin tehdyille, hyvässä kunnossa oleville, nuorille (alle $1 / 2$ kestoajasta) rakennuksille. Vanhojen sekä heikossa kunnossa olevien rakennusten kestoaika on arvioitu rakennusten kunnon ja niiden käyttökelpoisuuden perusteella. Niinpä mm. eräät asuinrakennukset olivat jo arviohetkellä yli 80 vuoden ikäisiä. Näiden jäljellä oleva kestoaika on arvioitu ottamalla huomioon vain se osa kestoajasta, mikä rakennuksia voidaan kohtuudella käyttää suorittamatta niissä huomattavia uudistuksia. Vastaavasti eräät varsin nuoret rakennukset olivat jo lähes loppuun käytettyjä. Näitten kestoaikaa arvioitaessa on menetelty kuten vanhoja rakennuksia käsiteltäessä on jo mainittu.

Rakennusten nykyarvo on laskettu niiden jälleenhankinta-arvosta käyttäen tasapoistomenetelmää. Rakennukset, joissa on tehty huomattavan suuria korjauksia, on arvioitu korjausten jälkeen vallitsevan tilanteen mukaan. Niiden kestoikä on arvioitu niinikään korjaushetkestä alkaen ottaen huomioon edellä esitetyt näkökohdat.

80
40
45
60
50
60
80




\section{Rakennusten pinta-ala ja tilavuus}

Asuinrakennusten pinta-alaan on laskettu lämpimien huoneiden, eteisten, komeroiden ja portaikkojen ala. Myös toisen kerroksen lämpimien huoneiden pinta-ala on otettu mukaan. Sen sijaan esitettyihin lukuihin eivät kuulu kylmät eteiset, kuistit, portaikot y.m. sellaiset. Rakennusten arvoa laskettaessa nämä on otettu huomioon (Taulukko 3).

Taulukko 3. Rakennusten pinta-ala $\mathrm{m}^{2}$ viljelmää ja muunnettua peltohehtaaria kohti viljelmäsuuruusluokittain.

Table 3. Area of the buildings in sq.m. per farms and converted hectare of arable land, by farm size class.

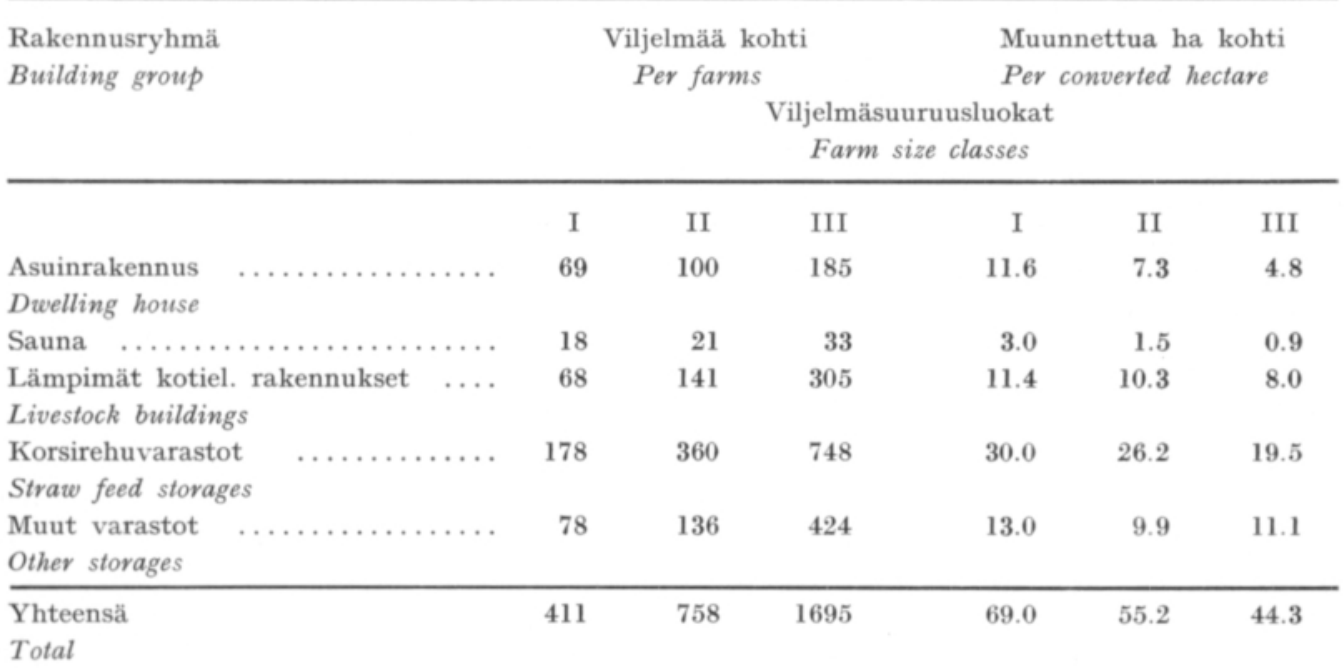

Taulukko 4. Rakennusten tilavuus $\mathrm{m}^{3}$ viljelmää ja muunnettua peltohehtaaria kohti viljelmäsuuruusluokittain.

Table 4. Volume of the buildings in cu.m. per farm and converted hectare of arable land, by farm size class.

\begin{tabular}{|c|c|c|c|c|c|c|}
\hline \multirow[t]{3}{*}{$\begin{array}{l}\text { Rakennusryhmä } \\
\text { Building group }\end{array}$} & \multicolumn{3}{|c|}{$\begin{array}{l}\text { Viljelmää kohti } \\
\text { Per farms }\end{array}$} & \multicolumn{3}{|c|}{$\begin{array}{l}\text { Muunnettua ha kohti } \\
\text { Per converted hectare }\end{array}$} \\
\hline & \multicolumn{6}{|c|}{$\begin{array}{l}\text { Viljelmäsuuruusluokat } \\
\text { Farm size classes }\end{array}$} \\
\hline & I & II & III & I & II & III \\
\hline $\begin{array}{l}\text { Asuinrakennus } \quad \ldots \ldots \ldots \ldots \ldots \ldots \\
\text { Dwelling house }\end{array}$ & 226 & 344 & 667 & 38.0 & 25.1 & 17.4 \\
\hline Sauna $\quad \ldots \ldots \ldots \ldots \ldots \ldots \ldots \ldots \ldots$ & 42 & 53 & 91 & 7.0 & 3.8 & 2.4 \\
\hline $\begin{array}{l}\text { Lämpimät kotiel. rakennukset } \quad \ldots . \\
\text { Livestock buildings }\end{array}$ & 183 & 399 & 940 & 30.8 & 29.1 & 24.5 \\
\hline $\begin{array}{l}\text { Korsirehuvarastot } \ldots \ldots \ldots \ldots \ldots \ldots \\
\text { Straw feed storages }\end{array}$ & 523 & 1092 & 2510 & 87.9 & 79.6 & 65.5 \\
\hline $\begin{array}{l}\text { Muut varastot } \quad \ldots \ldots \ldots \ldots \ldots \ldots \ldots \\
\text { Other storages }\end{array}$ & 217 & 432 & 1383 & 36.5 & 31.5 & 36.1 \\
\hline $\begin{array}{l}\text { Yhteensä } \\
\text { Total }\end{array}$ & 1191 & 2320 & 5591 & 200.2 & 169.1 & 145.9 \\
\hline
\end{tabular}


Saunan pinta-alaan kuuluvat puku- ja pesuhuone sekä varsinainen sauna. Saunan yhteyteen rakennetut halkovajat on luettu ryhmään muut varastot.

Lämpimien kotieläinrakennusten alaan on laskettu navetan, tallin, sikalan ja kanalan pinta-ala. Myös karjakeittiö ja maitohuone sekä lämmin eteinen ja lämpimät komerot kuuluvat tähän ryhmään. Lantalan, kylmien jauhovarastojen sekä kylmien eteisten alaa ei ole otettu mukaan. Jos kotieläinrakennus on ollut kaksikerroksinen, on myös toisen kerroksen lattia-ala, joka on tehty kotieläinten käyttöön soveltuvaksi, laskettu pinta-alaan kuuluvaksi.

Korsirehuvarastojen ryhmään on laskettu kuuluvaksi ladot, puimalat ja kotieläinrakennusten ullakot, jos näitä on käytetty heinä- tai olkivarastoina sekä AIVtornit. AIV-torneja oli ainoastaan 21 viljelmällä. Korsirehuvarastojen kokonaistilavuudesta AIV-tornien osuus oli $1.3 \%$.

Muut varastot sisältävät kaikki ne maatalousrakennukset, joita ei ole luettu edellisiin ryhmiin. Näihin kuuluvat kalustovajat, aitat, viljavarastot, riihet, kellarit, halkovajat ja näihin verrattavat. Riihiä käytettiin yleisesti viljavarastoina ja viljankuivaamoina, mutta ei juuri ollenkaan olki- ja heinävarastoina. Siksi riihet on luettu ryhmään muut varastot. Tutkittujen viljelmien rakennusten pinta-alat ja tilavuudet on esitetty taulukoissa 3 ja 4 .

\section{Asuinrakennukset}

Asuinrakennusten keskimääräinen ala lisääntyy huomattavasti viljelmän koon kasvaessa. Tämän tutkimuksen mukaan on asuinrakennusten ala viljelmää kohti keskimäärin 89 m²$^{2}$. MÄEN (s. 17, 135) vuoden 1938:n rakennusaloja koskevan tutkimuksen mukaan oli Pohjois-Karjalassa asuinrakennusten keskimääräinen ala viljelmää kohti $107 \mathrm{~m}^{2}$. Molempiin tutkimuksiin kuuluneiden viljelmien keskimääräinen peltoala on suunnilleen sama. Myös suuruusluokittain asuntojen alaa tarkasteltaessa on selvästi havaittavissa, että asuinrakennukset Mäen tutkimuksen mukaan ovat olleet kussakin viljelmäsuuruusluokassa suurempia kuin tämän tutkimuksen aikana. On todennäköistä, että kahden viimeisen vuosikymmenen aikana on yleisesti rakennettu keskikokoisilla ja suurilla viljelmillä pienempiä asuinrakennuksia kuin viime vuosisadalla ja tämän vuosisadan alussa. Alla oleva asetelma, jossa on esitetty vuosina 1941-1960 rakennettujen ja ennen vuotta 1941 rakennettujen asuinrakennusten keskimääräinen ala viljelmäsuuruusluokittain, tukee esitettyä olettamusta.

$\begin{array}{cc}\text { Viljelmä- } & \text { Vuosina } 1941-1960 \\ \text { suuruusluokka } & \text { rakennetut } \\ \text { I } & 69 \mathrm{~m}^{2} \\ \text { II } & 86 \\ \text { III } & 112\end{array}$

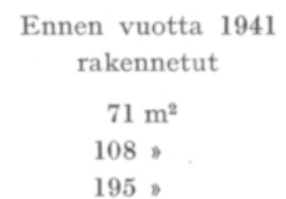

Vuosina 1941-1960 rakennettuja asuinrakennuksia kuuluu tutkimusaineistoon $48.4 \%$. Tähän tutkimukseen kuuluvien asuinrakennusten pienempi koko johtuneekin huomattavalta osalta siitä, että uudet rakennukset ovat vanhoja pienempiä ja näin keskikoko jää pienemmäksi kuin Mäen tutkimuksen mukaan. 
Viljelmällä työskentelevien ja niillä asuvien henkilöitten keskimääräinen luku oli tutkituissa tapauksissa sitä suurempi mitä enemmän viljelmällä oli peltoa. Kun henkilöluku viljelmän koon kasvaessa ei kuitenkaan lisäänny samassa suhteessa kuin asuntojen ala, jää suurilla viljelmillä henkilöä kohti enemmän lattia-alaa kuin pienillä viljelmillä. Seuraavassa asetelmassa on esitetty henkilöluku viljelmää kohti ja keskimääräinen asunnon $\mathrm{m}^{2}$ määrä henkilöä kohti tutkituilla viljelmillä.

$\begin{array}{ccc}\begin{array}{c}\text { Viljelmä- } \\ \text { suuruusluokka }\end{array} & \text { Henkilöluku } & \begin{array}{c}\text { Asunnon ala } \\ \mathrm{m}^{2} / \text { henkilö }\end{array} \\ \text { I } & 3.93 & 17.6 \\ \text { II } & 4.70 & 21.3 \\ \text { III } & 6.50 & 28.5\end{array}$

Asuntojen ala poikkeaa monessa yksityistapauksessa huomattavasti keskiarvoista. Alla olevassa asetelmassa eri suuruusluokkiin kuuluvat viljelmät on ryhmitelty asunnon pinta-alan perusteella.

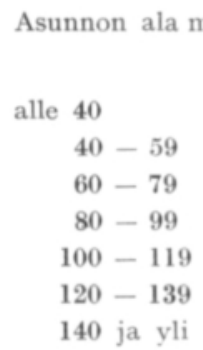

\begin{tabular}{rrr}
\multicolumn{4}{c}{ Viljelmien luku } \\
I lk & II lk & III lk \\
6 & - & - \\
18 & 5 & - \\
23 & 11 & - \\
15 & 14 & - \\
4 & 4 & 1 \\
3 & 5 & - \\
1 & 11 & 7
\end{tabular}

Ensimmäisen viljelmäsuuruusluokan tyypillisin asunto kuuluu luokkaan 60 $79 \mathrm{~m}^{2}$, toisen luokkaan $80-99 \mathrm{~m}^{2}$ ja kolmannen luokkaan $140-159 \mathrm{~m}^{2}$. Kuudella toisen ja kolmannen suuruusluokan viljelmällä pidettiin palkattuja, vieraita työntekijöitä, jotka asuivat näillä viljelmillä. Muissa tapauksissa asunto oli kokonaan oman perheen käytössä.

\section{Lämpimät kotieläinrakennukset}

Tutkituilla 129:llä viljelmällä oli 127 navettaa tai yhdistettyä kotieläinrakennusta, 48 tallia, 5 sikalaa ja 1 kanala. Yhden viljelmän lehmät pidettiin naapurilta vuokratussa navetassa. Yhdeltä viljelmältä navetta oli keväällä purettu, mutta uuden rakentaminen oli tutkimusaineistoa koottaessa suunnitteilla. Kotieläinrakennusten jakaminen nautaeläinten, hevosten, sikojen, kanojen ja lampaiden kesken on vaikeaa. Yhdistetyissä kotieläinrakennuksissa oli useita, joissa seinä erotti navetan ja tallin toisistaan, mutta lämpimät aputilat, kuten eteiset, työvälinekomerot, käytävät, keittiöt sekä väkirehuille ja juurikasveille varatut tilat olivat yhteisiä. Monilla pienillä viljelmillä hevosta pidettiin navetassa. Varsin yleistä oli, että tallissa pidettiin hiehoja, vasikoita, lampaita tai sikoja. Tarkkaa rajaa siitä, mikä rakennus tai rakennuksen osa käytetään millekin eläinlajille, ei näytä esiintyvän 
kuin harvoissa tapauksissa. Tästä syystä käsillä olevassa tutkimuksessa on menetelty siten, että eri kotieläinten käyttämiä tiloja ei ole laskettu erikseen, vaan kaikki on ilmoitettu ryhmänä lämpimät kotieläinrakennukset.

Taulukko 3 osoittaa lämpimien kotieläinrakennusten keskimääräisen alan viljelmää ja peltohehtaaria kohti. Kotieläinrakennusten ala viljelmää kohti lisääntyy mutta peltohehtaaria kohti pienenee viljelmän peltoalan lisääntyessä. Taulukossa 3 käytetty viljelmäsuuruusluokkajaoitus, joka on sama kuin maatalouskirjanpidossa käytetty jaoitus, on tehty niin suurin luokkavälein, että eräitä tutkittujen viljelmien rakennusten määrään liittyviä yleisiä piirteitä katoaa. Seuraavassa tarkastelussa tutkimusaineisto on jaettu alla esitetyin luokkavälein viljelmäsuuruusluokkiin.

\begin{tabular}{rccc}
\multicolumn{1}{c}{ Luokat } & $\begin{array}{c}\text { Havaintojen } \\
\text { luku }\end{array}$ & Luokat & $\begin{array}{c}\text { Havaintojen } \\
\text { luku }\end{array}$ \\
$2.00-3.99$ & 19 & $12.00-14.99$ & 12 \\
$4.00-5.99$ & 13 & $15.00-19.99$ & 13 \\
$6.00-7.99$ & 11 & $20.00-29.99$ & 4 \\
$8.00-7.99$ & 19 & $30.00-39.99$ & 4 \\
$10.00-11.99$ & 22 & $40.00-49.99$ & 3
\end{tabular}

Ne viljelmät, joille maatilan jaon tai muuten tapahtuneen peltoalan luovutuksen seurauksena on jäänyt suhteettoman suuret kotieläinrakennukset, on jätetty tämän tarkastelun ulkopuolelle. Kustakin viljelmäsuuruusluokasta on muodostettu kotieläinrakennuksen iän mukaan kaksi luokkaa. Toiseen kuuluvat ne viljelmät, joiden kotieläinrakennusten ikä on ollut alle 20 vuotta ja toiseen ne viljelmät, joilla on tätä vanhemmat kotieläinrakennukset. Luokkien keskiarvoista on muodostettu seuraavat funktiot:

a. alle 20 vuotiaat kotieläinrakennukset:

$$
\mathrm{Y}=0.46+0.64 \log (\mathrm{x}+15)-0,01(\mathrm{x}+15) ; \mathrm{R}^{2}=0.73
$$

b. 20 vuotiaat ja sitä vanhemmat kotieläinrakennukset:

$$
\mathrm{Y}=2,19-0,83 \log \mathrm{x}-2,95 \frac{\mathbf{1}}{\mathrm{x}} ; \mathrm{R}^{2}=0,74
$$

Kuvioon 1 on piirretty funktioitten kuvaajat ja lisäksi käyrä, joka esittää maatalousministeriön asutusasiainosaston rakennustoimiston (ASO) ohjeiden (16) mukaan laskettua viljelmän kotieläinrakennusten tarvetta.

Tutkimusaineistosta laskettujen funktioitten kuvaajat poikkeavat oleellisesti ohjeellisesta käyrästä. ASO:n ohjeiden, samoin esittää myös AspialA (3, s. 4-7), mukaan viljelmän peltoalan lisääntyessä kotieläinrakennusten määrän peltohehtaaria kohti tulisi supistua. Tutkituissa tapauksissa keskimääräinen lämmin kotieläinrakennusala peltohehtaaria kohti aluksi lisääntyy noin kahdeksaan peltohehtaariin saakka, jonka jälkeen se alkaa supistua, mutta supistuminen on etenkin nuorten kotieläinrakennusten kohdalla aluksi hidasta. Kotieläinrakennusten ala $\mathrm{m}^{2}$ /ha on ollut tutkituilla $8-20$ peltohehtaarin viljelmillä noin $2.5-4 \mathrm{~m}^{2} / \mathrm{ha}$ suurempi kuin kuvioissa mainitut ohjeet edellyttäisivät. 


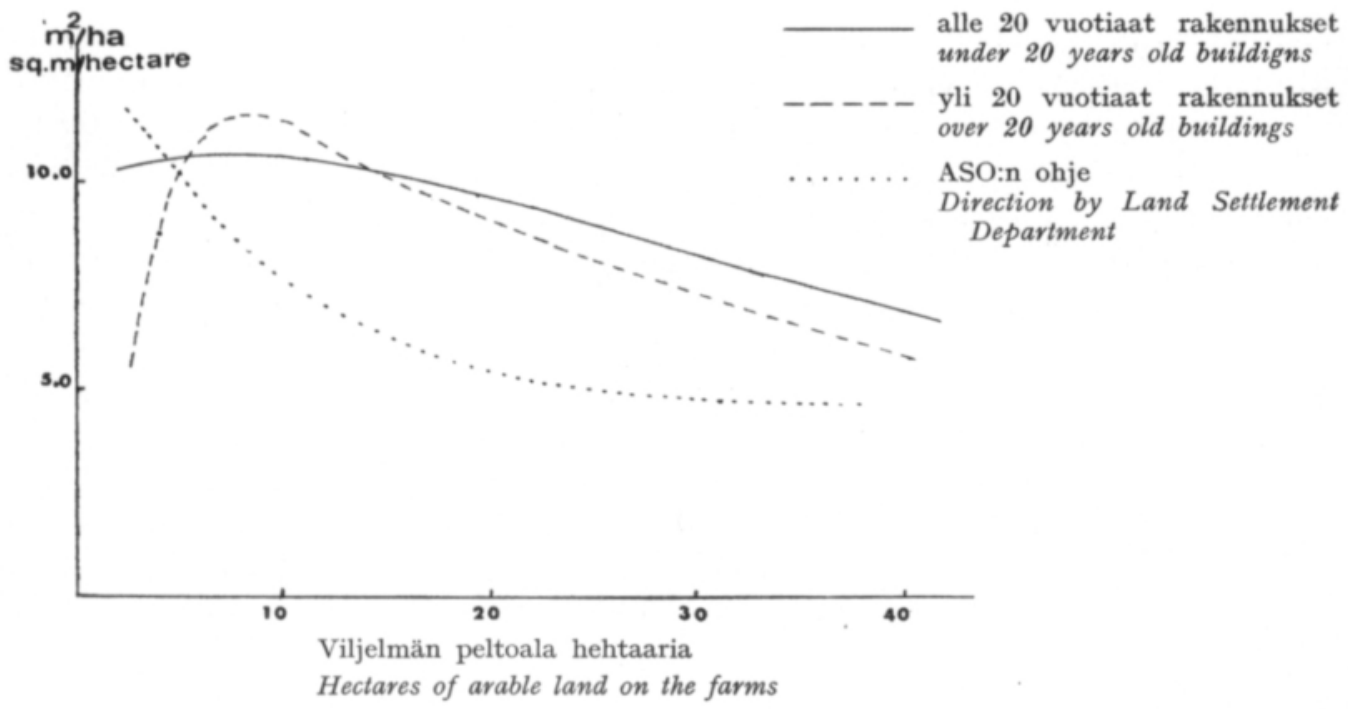

Kuvio 1. Kotieläinrakennusten ala $\mathrm{m}^{2}$ peltohehtaaria kohti tutkituilla viljelmillä.

Fig. 1. Area of livestock buildings, sq.m. per hectare of arable land.

Kuviossa 2 on esitetty nautayksiköiden luku peltohehtaaria kohti tutkituilla viljelmillä ja koko maassa. Kuviossa 1 esitetty, rakennustarvetta (ASO:n ohje) kuvaava käyrä ja ny-lukua osoittavat käyrät (kuvio 2) ovat muodoltaan lähes identtisiä. Nautayksiköiksi muuntaminen on tässä yhteydessä suoritettu eläinten tarvitseman lattia-alan suhteessa. Tätä on käsitelty yksityiskohtaisemmin sivulla 37 .

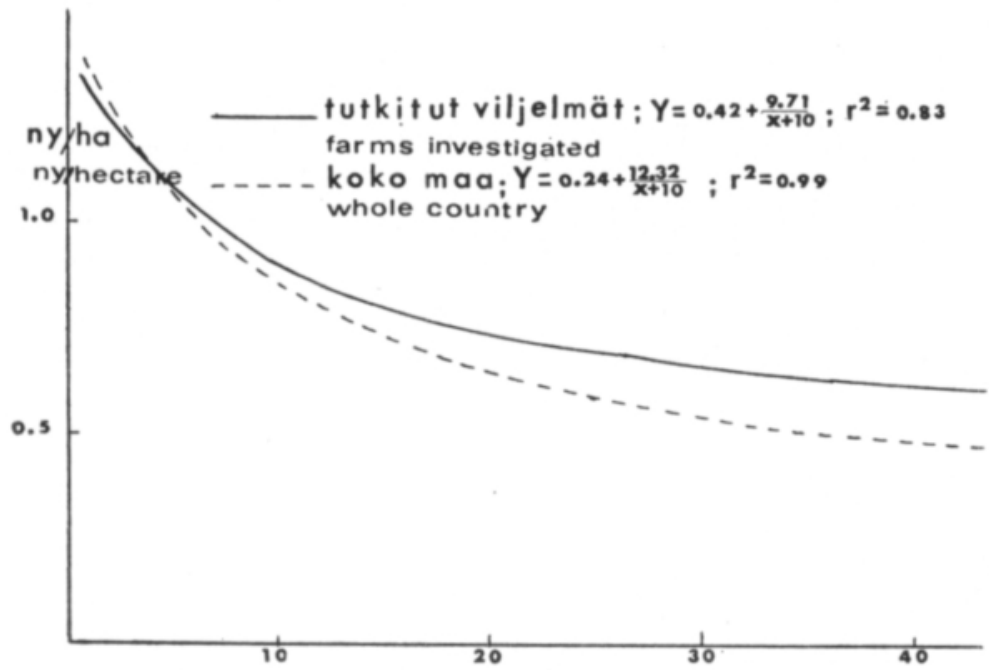

Viljelmän peltoala hehtaaria

Hectares of arable land on the farm

Kuvio 2. Nautayksiköiden luku peltohehtaaria kohti tutkituilla viljelmillä ja koko maassa.

Fig. 2. Number of livestock units per hectare of arable land on the farms investigated and in the country as a whole. 
Noin 8 peltohehtaaria pienemmillä viljelmillä lämmin kotieläinrakennusala hehtaaria kohti vähenee, vaikka kotieläinten määrä hehtaaria kohti lisääntyy. Tähän on päästy osittain siten, että karjakeittiö on jätetty rakentamatta suhteellisesti sitä useammassa tapauksessa mitä pienempi viljelmä on ollut. Myös maidon jäähdytyshuone ja vieläpä lämpimän pitävä eteinenkin puuttuivat monen pienen viljelmän kotieläinrakennuksesta. Kirjoittajan käsityksen mukaan vain muutamien pienten viljelmien navetoissa oli havaittavissa suoranaista tilan ahtautta. Kun tutkittujen, pienimpien viljelmien kotieläinrakennukset olivat melkein yksinomaan puurakenteisia, ne lyhytikäisempinä kuin suurempien viljelmien kivirakenteiset rakennukset paremmin vastasivat tutkimushetken rakennustarvetta.

Tutkittujen viljelmien kotieläinrakennusten ala peltohehtaaria kohti vaihtelee suuresti. Kuvio 3:n kumulatiivinen frekvenssikäyrä esittää peltohehtaaria kohti lasketun lämpimän pitävän kotieläinrakennusalan viljelmäsuuruusluokittain. Kuvio valaisee sitä hajontaa, joka aineistossa vallitsee. Hajontaa on tarkasteltu myös

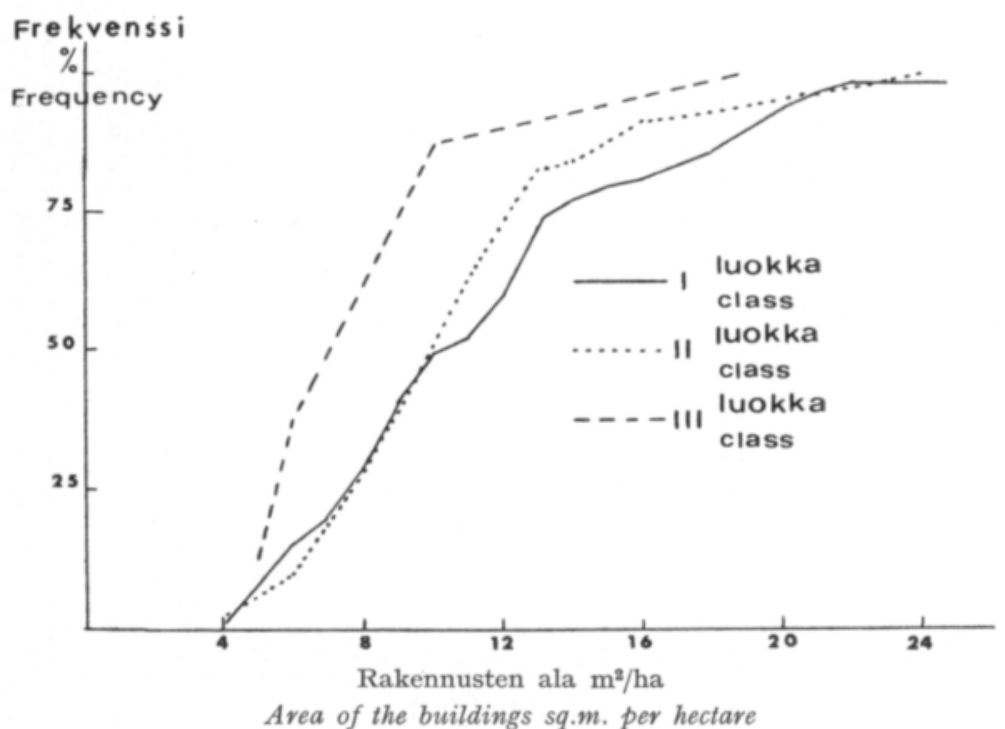

Kuvio 3. Kotieläinrakennusten ala $\mathrm{m}^{2}$ peltohehtaaria kohti tutkituilla viljelmillä viljelmäsuuruusluokittain. Kumulatiivinen frekvenssi.

Fig. 3. Area of livestock buildings, sq.m./hectare of arable land on the farms investigated, by farm size class. Cumulative frequency.

taulukossa 5. Kuviosta 3 voidaan lukea mm., että sellaisten viljelmien osuus, joilla kotieläinrakennusten ala hehtaaria kohti on $10 \mathrm{~m}^{2}$ tai pienempi, on $49 \%$ I luokan, $52 \%$ II luokan ja $87 \%$ III luokan viljelmien luvusta tai, että $30 \%$ I luokan viljelmistä on sellaisia, joilla on ollut kotieläinrakennusalaa enemmän kuin $12,8 \mathrm{~m}^{2} / \mathrm{ha}$.

Taulukossa 5 on esitetty eri ikäisten kotieläinrakennusten keskimääräinen ala peltohehtaaria kohti sekä standardipoikkeama. Rakennusten ikä on laskettu navetan tai yhdistetyn kotieläinrakennuksen iän mukaan. Eri ikäluokkien sisäinen 
Taulukko 5. Tutkittujen viljelmien kotieläinrakennusten ala $\mathrm{m}^{2} / \mathrm{ha}$ ikä- ja viljelmäsuuruusluokittain. Table 5. The area, sq.m./hectare, of the livestock buildings of the farms investigated by age and farm size class.

\begin{tabular}{|c|c|c|c|c|c|c|}
\hline \multicolumn{7}{|c|}{$\begin{array}{c}\text { Vil j e } 1 \mathrm{~m} \text { äs u u r u s } 1 \text { uok a t } \\
\text { Farm size classes }\end{array}$} \\
\hline & I & & II & & III & \\
\hline $\begin{array}{c}\text { Rakennusten } \\
\text { ikä } \\
\text { vuotta } \\
\text { Age of the } \\
\text { buildings }\end{array}$ & $\begin{array}{l}\text { Havaint. } \\
\text { luku } \\
\text { Number of } \\
\text { observations }\end{array}$ & $\begin{array}{l}\text { Keskiarvo } \\
\text { ja stand.p. } \\
\text { Mean and } \\
\text { standard } \\
\text { deviation }\end{array}$ & $\begin{array}{l}\text { Havaint. } \\
\text { luku } \\
\text { Number of } \\
\text { observation }\end{array}$ & $\begin{array}{l}\text { Keskiarvo } \\
\text { ja stand.p. } \\
\text { Mean and } \\
\text { standard } \\
\text { deviation }\end{array}$ & $\begin{array}{l}\text { Havaint. } \\
\text { luku } \\
\text { Number of } \\
\text { observation }\end{array}$ & $\begin{array}{c}\text { Keskiarvo } \\
\text { ja stand.p. } \\
\text { Mean and } \\
\text { standard } \\
\text { deviation }\end{array}$ \\
\hline$>10$ & 26 & $13.3 \pm 5.3$ & 16 & $11.7 \pm 2.9$ & 1 & 5.0 \\
\hline $10-19$ & 18 & $10.5 \pm 3.4$ & 7 & $9.6 \pm 3.2$ & 2 & 6.3 \\
\hline $20-29$ & 13 & $12.2 \pm 5.5$ & 6 & $9.6 \pm 2.4$ & - & - \\
\hline $30-39$ & 6 & $10.0 \pm 4.4$ & 8 & $8.7 \pm 4.6$ & - & - \\
\hline $40-49$ & 3 & $11.2 \pm 9.7$ & 4 & $9.1 \pm 1.9$ & 3 & 12.0 \\
\hline $50-59$ & - & - & 3 & $10.6 \pm 1.4$ & 2 & 8.3 \\
\hline $60-69$ & 1 & 51.8 & 4 & $16.8 \pm 7.3$ & & \\
\hline $70<$ & 2 & 6.1 & 2 & 11.8 & & \\
\hline Koko aineisto & 69 & $11.4 \pm 7.0$ & 50 & $10.3 \pm 4.0$ & 8 & $8.0 \pm 4.5$ \\
\hline
\end{tabular}

Total material

hajonta on pienempi kuin kyseessä olevan viljelmäsuuruusluokan sisäinen hajonta. Poikkeuksen tekevät vain ensimmäisen viljelmäsuuruusluokan 5. ja toisen suuruusluokan 7. ikäluokka. Juuri näissä ikäluokissa ovat ne I:n ja II suuruusluokan viljelmät, joille tilan jaossa oli jäänyt tarpeettoman suuret kotieläinrakennukset.

Kolmas osa kaikista havainnoista kuuluu ensimmäiseen ikäluokkaan, jossa kotieläinrakennusten ikä on alle 10 vuotta. Alle 20 vuotiaita kotieläinrakennuksia on ollut $54.3 \%$ kaikista tutkituista tapauksista. Näillä viljelmillä kotieläinrakennukset on suunniteltu ja rakennettu viljelmän nykyistä tarvetta varten. Merkille pantavaa on, että nuorimmat kotieläinrakennukset ovat eräitä poikkeuksia lukuunottamatta suurempia kuin vanhemmat.

Uusimmat navetat on pyritty rakentamaan jonkin verran täydellisemmiksi kuin vanhemmat. Karjakeittiö ja maitohuone on useissa ensimmäisenkin viljelmäsuuruusluokan navetoissa. Nämä lisäävät uusien navettojen lämmintä lattia-alaa. Tämä selittänee osan uusien ja vanhojen navettojen välisestä erosta. Syitä voi olla muitakin. Näitä tarkastellaan vielä kapasiteetin hyväksikäyttöä koskevassa kappaleessa.

\section{Korsirehuvarastot}

Korsirehuvarastojen määrä on ilmoitettu kuutiometreinä. Taulukkoon 3 on otettu mukaan myös varastojen pinta-ala. Ilmoitetut luvut osoittavat ainoastaan varaston pohjakerroksen alan. Korsirehuvarastojen keskimääräinen tilavuus viljelmää ja peltohehtaaria kohti on esitetty taulukossa 4. Viljelmää kohti laskettuna 


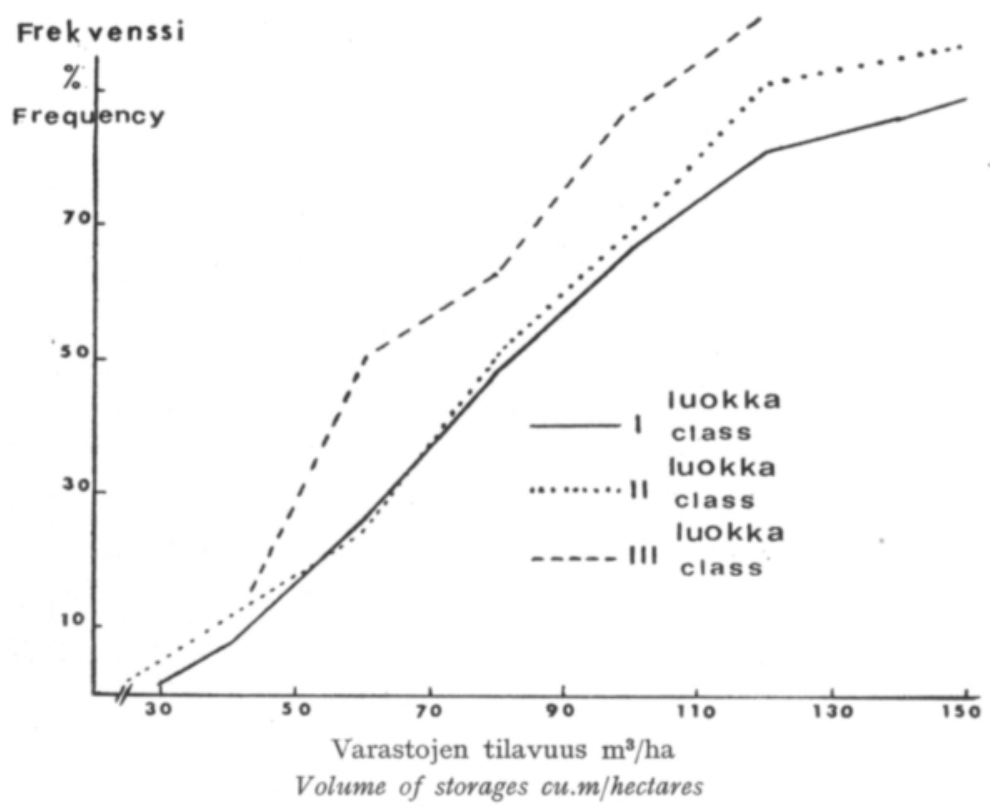

Kuvio 4. Korsirehuvarastojen tilavuus $\mathrm{m}^{3} / \mathrm{ha}$ tutkituilla viljelmillä viljelmäsuuruusluokittain. Kumulatiivinen frekvenssi.

Fig. 4. Volume of straw feed storages, cu.m/hectare, on the farms studied, by farm size class. Cumulative frequency.

varastojen määrä lisääntyy suuresti viljelmän peltoalan kasvaessa, mutta peltohehtaaria kohti se pienenee taulukon 4 osoittamalla tavalla.

Aspiala (3, s. 8) laskee 5 peltohehtaarin viljelmällä tarvittavan korsirehujen säilytystilaa, jos rakennukset on sijoitettu keskitetysti, $52 \mathrm{~m}^{3} / \mathrm{ha}$ ja 15 sekä 30 peltohehtaarin viljelmillä $50 \mathrm{~m}^{3} /$ ha. Tutkituilla I:n suuruusluokan viljelmillä oli korsirehuvarastoja $76 \%$, II:n suuruusluokan viljelmillä $59 \%$ ja III:n suuruusluokan viljelmillä $31 \%$ enemmän kuin korsirehuvarastoja yllä esitetyn mukaan on lasketty tarvittavan. Tutkituista viljelmistä oli ainoastaan $12.4 \%$ sellaisia, joilla korsirehuvarastot oli keskitetty yhden katon alle.

Korsirehuvarastojen tilavuus peltohehtaaria kohti vaihtelee yksityisillä viljelmillä suuresti. Kuviossa 4 on esitetty tutkittujen viljelmien korsirehuvarastojen tilavuus $\mathrm{m}^{3} /$ ha viljelmäsuuruusluokittain kumulatiivisenä frekvenssikäyränä.

Viljelmiä, joiden korsirehuvarastojen tilavuus oli alle $40 \mathrm{~m}^{3}$ ha kohti oli viisi. Näistä kolmella oli selvästi liian vähän varastotilaa. Varastotilaa oli $40-60 \mathrm{~m}^{3} / \mathrm{ha}$ 28:lla viljelmällä. Kirjoittajan saaman käsityksen mukaan näistä oli enää kaksi selvästi puutteellisesti rakennettua. Viljelmistä, joilla oli rehuvarastoja yli $60 \mathrm{~m}^{3} / \mathrm{ha}$, kirjoittajan on tuntemuksensa perusteella vaikea sanoa, olisiko yhdelläkään ollut liian vähän varastotilaa korsirehuja varten. Sitä vastoin oli havaittavissa, että usealla viljelmällä oli liian suuri määrä varastoja. Käsillä olevassa tutkimuksessa puimalat on luettu korsirehuvarastoihin. Yleensä niillä viljelmillä, joilla heinälatojen ja muiden heinäsuojien ohella oli rakennettu myös puimala, varastotilaa oli runsaasti. Useiden viljelmien rehuvarastot oli joko olosuhteiden pakosta tai jostakin 
muusta syystä rakennettu hyvin hajalle. Näissä tapauksissa varastojen määrä oli tavallisesti suuri. Sangen monissa tapauksissa ei voida kuitenkaan löytää syytä siihen, miksi oli rakennettu tarpeettoman suuret varasto- ja kotieläinrakennukset. Eräs maanviljelijä, joka oli perinyt isältään noin 50 peltohehtaarin viljelmän, ilmaisi erään, ehkä sangen keskeisen syyn. Tällä viljelmällä oli kotieläinrakennus, jossa oli tilaa noin 50 lehmälle ja 10 hevoselle. Mainitun maanviljelijän kertoman mukaan hänen isällään oli tavoitteena rakentaa monumentti (navetta), jollaista siitä pitäjästä ei löydy ja niinpä hän rakennutti hakkukivestä tuon 50 lehmän navetan. Nyt siinä rakennuksessa oli 26 nautayksikköä kotieläimiä.

\section{Munt varastot}

Tähän ryhmään kuuluvien varastojen pinta-ala ja tilavuus peltohehtaaria kohti oli ensimmäisessä viljelmäsuuruusluokassa suurin ja toisessa pienin. Kolmannessa luokassa on näitä rakennuksia peltohehtaaria kohti lähes yhtä paljon kuin ensimmäisessä (taulukot 3 ja 4). Kaikilla kolmanteen suuruusluokkaan kuuluvilla viljelmillä oli kalustovaja, toiseen luokkaan kuuluvilla se oli $68 \%$ :lla ja ensimmäiseen luokkaan kuuluvilla $48 \%$ :lla. Monella I:n ja II:n suuruusluokan viljelmillä oli ainoastaan pieni halkovaja tai pelkkä katos, jossa polttopuut säilytettiin. Katokset on jätetty pois rakennusten tilavuutta laskettaessa. Usealla pienellä viljelmällä myös viljavarastot olivat sangen vähäiset. Kun III:n suuruusluokan ja osittain myös II suuruusluokan viljelmille oli rakennettu tarvittava määrä kalusto- ja polttopuuvajoja sekä viljavarastoja, on näistä toimenpiteistä ollut seurauksena, että näillä viljelmillä ryhmän - muut varastot - määrä hehtaaria kohti on suunnilleen yhtä suuri kuin pienillä viljelmillä.

\section{Rakennusten ikä}

Maatilan eri rakennusten ikä on saatu tiedustelemalla viljelijältä rakennusten perustamisvuosi ja laskemalla ikä sen mukaan. Asuinrakennuksen ja navetan tai kotieläinrakennuksen perustamisvuosi voitiin lähes kaikissa tapauksissa ilmoittaa vuoden tarkkuudella. Eräissä tapauksissa hirsisten latojen ja aittojen perustamisvuosi ei ollut tiedossa. Näiden rakennusten ikä on arvioitu. Jos asuinrakennuksissa tai kotieläinrakennuksissa oli tehty niin suuri korjaus, että se vastasi selvästi enemmän kuin puolet vastaavan uuden rakentamiskustannuksista, on korjausvuosi merkitty rakennuksen perustamisvuodeksi.

Taulukossa 6 on esitetty rakennusten keski-iät viljelmäsuuruusluokittain. Asuinrakennusten, saunojen ja kotieläinrakennusten keski-ikä on aritmeettinen keskiarvo yksityisten rakennusten iästä. Varastojen keski-ikä on laskettu painotettuna keskiarvona. Varastot on ryhmitetty viljelmäsuuruusluokittain iän perusteella luokkiin. Luokkavälinä on käytetty 10 vuotta. Viljelmäsuuruusluokan keski-ikä on saatu painottamalla kunkin ikäluokan keski-ikä tähän ikäluokkaan kuuluvien varastojen kuutiomäärällä. 
Taulukko 6. Rakennusten keski-ikä tutkituilla viljelmillä viljelmäsuuruusluokittain.

Table 6. Mean age of the buildings, by farm size class.

\begin{tabular}{|c|c|c|c|}
\hline \multirow{2}{*}{$\begin{array}{l}\text { Rakennus tai rakennusryhmä } \\
\text { Building or group of buildings }\end{array}$} & \multicolumn{3}{|c|}{$\begin{array}{c}\text { V i } 1 \mathrm{j} \text { e } 1 \mathrm{~m} \text { äs u u u u } 1 \text { u o k t } \\
\text { Farm size classes }\end{array}$} \\
\hline & I & II & III \\
\hline $\begin{array}{l}\text { Asuinrakennus } \quad \ldots \ldots \ldots \ldots \ldots \ldots \ldots \ldots \ldots \cdots \cdots \\
\text { Dwelling house }\end{array}$ & 21 & 36 & 53 \\
\hline 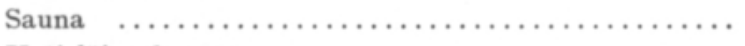 & 15 & 20 & 16 \\
\hline $\begin{array}{l}\text { Kotieläinrakennus } \quad \ldots \ldots \ldots \ldots \ldots \ldots \ldots \ldots \ldots \cdots \cdots \cdots \\
\text { Livestock building }\end{array}$ & 19 & 23 & 39 \\
\hline $\begin{array}{l}\text { Korsirehuvarastot } \quad \ldots \ldots \ldots \cdots \cdots \cdots \cdots \cdots \cdots \cdots \cdots \cdots \cdots \cdots \\
\text { Straw feed storages }\end{array}$ & 17 & 20 & 28 \\
\hline $\begin{array}{l}\text { Muut varastot } \quad \ldots \ldots \ldots \ldots \ldots \ldots \ldots \ldots \ldots \ldots \ldots \ldots \cdots \\
\text { Other storages }\end{array}$ & 17 & 26 & 32 \\
\hline
\end{tabular}

Tutkimusalueen maatalousrakennukset ovat yleensä nuoria. SKovgaARD (24, s. 16) on tutkinut Tanskan maatalousrakennusten ikärakennetta ja todennut, että eri rakennusten keski-ikä vuonna 1950 oli seuraava:

$\begin{array}{lc}\text { Asuinrakennukset } & 59 \text { vuotta } \\ \text { Navetat } & 50 \\ \text { Ladot, ym. } & 44 \\ \text { Kanalat } & 24\end{array}$

Tähän tutkimukseen kuuluvilla I:n ja II:n suuruusluokan viljelmillä rakennusten keski-ikä oli vähemmän kuin puolet Tanskan maatalousrakennusten keski-iästä.

Rakennusten keski-ikä lisääntyy viljelmän peltoalan lisääntyessä. Ero on erityisen selvä asuinrakennusten iän välillä. Myös kotieläin- ja varastorakennukset ovat huomattavan vanhoja kolmannen suuruusluokan viljelmillä. Sitävastoin ensimmäisen ja toisen suuruusluokan viljelmillä näiden rakennusryhmien erot ovat verraten pienet.

Erot eri viljelmäsuuruusluokkien rakennusten keski-iän välillä saattavat johtua $\mathrm{mm}$. siitä, että suuremmilla viljelmillä olisi rakennettu kestävämmät rakennukset kuin pienemmillä. On sangen todennäköistä, että mitä suurempia maatalousrakennuksia on pystytetty, sitä enemmän on käytetty ammattihenkilöiden laatimia suunnitelmia ja valvontaa rakennustoiminnassa. Hyvän suunnittelun ja tarkoitukseen soveltuvien rakennusaineiden käytön on yleisesti todettu pidentävän rakennusten käyttöikää.

Tutkimusaineistoon kuuluvat pienet viljelmät ovat huomattavalta osalta nuoria. Osa näistä on perustettu viimeisten vuosikymmenien aikana jakamalla tilat sisarusten kesken. Karjalaisen siirtoväen viime sodan jälkeen rakentamia tiloja oli ensimmäisessä luokassa 9, toisessa 8 . Yhteensä siirtoväen tiloja oli $14 \%$ näiden suuruusluokkien tiloista. Pienten viljemien omistajien taloudelliset mahdollisuudet rakentaa tämän vuosisadan kolmen ensimmäisen vuosikymmenen aikana rakennuksia, 
jotka olisivat edes tyydyttävästi vastanneet näillä viljelmillä 1950 -luvulla työskentelevien rakennuksille asettamia vaatimuksia, olivat tutkimusalueella sangen vähäiset. Siksi rakentamisen tarve pienillä viljelmillä sodan jälkeen on ollut suuri. Kun taloudelliset mahdollisuudet ovat parantuneet 1950-luvulla ja lainojen saanti pienten viljelmien rakentamista varten on helpottunut, on erityisesti uusien asuinja kotieläinrakennusten osuus näillä viljelmillä lisääntynyt voimakkaasti. Ensimmäisen suuruusluokan viljelmien asuinrakennuksista on rakennettu vuoden 1940 jälkeen $61.5 \%$ ja kotieläinrakennuksista $63.8 \%$. Toisen suuruusluokan viljelmien vastaavat prosentit olivat 36.0 ja 48.0 ja kolmannen suuruusluokan 12.5 ja 27.5. Ensimmäisessä viljelmäsuuruusluokassa 1940 jälkeen rakennettujen korsirehuvarastojen tilavuus oli $60.1 \%$ tämän luokan varastojen kokonaistilavuudesta, toisessa luokassa $54.8 \%$ ja kolmannessa luokassa $28.4 \%$.

\section{Rakennusaine}

Useissa maatalousrakennuksissa käytetään sekä puu- että kivirakennetta rinnakkain. Navetan seinät voivat olla sementtitiilestä, perustus, lattia ja laipio betonista, ullakkokerroksen seinät ja lattia sekä kattotuolit ja katon aluslaidoitus puuta, mutta katto taas tiilestä. Tästä syystä kokonaisia rakennuksia ei voida luokitella rakennusaineen perusteella, vaan luokittelu on suoritettava rakennusten eri osien mukaan. Tässä esitetään tutkimusaineistoon kuuluvien rakennusten seinien, lattioiden, laipioiden ja kattojen rakennusaine. Asuin- ja kotieläinrakennusten kohdalla on ilmoitettu, montako prosenttia viljelmäsuuruusluokan rakennusten luvuista oli hirsi-, lauta-, tiili-, betoni- tai kiviseinäisiä. Lattioiden, laipioiden ja kattojen rakennusaine on ilmoitettu samalla tavalla. Varastojen osalta on ilmoitettu montako prosenttia rakennusten tilavuudesta oli hirsi-, lauta- jne. seinäisiä. Myös lattioiden ja kattojen rakennusaineiden osuudet on laskettu tilavuuden eikä rakennusten luvun perusteella. Tulokset on esitetty taulukossa 7 .

Asuinrakennukset ovat lähes yksinomaan puurakenteisia. Vain kolme asuinrakennusta 129:stä oli kivirakenteista. Asuinrakennusten katto on ollut pääasiallisesti päreestä. Huopa, tiili tai peltikatot ovat harvalukuisia. Niitä on ollut eniten suurilla viljelmillä.

Kotieläinrakennuksista on sangen huomattava osa kivirakenteisia. Ensimmäisessä viljelmäsuuruusluokassa on $58.6 \%$ ja toisessa $84.0 \%$ kotieläinrakennusten seinistä kivirakenteisia. Kolmannessa luokassa esiintyy vain kivirakenteisia seiniä. Lattiat ovat pääasiassa betonia, joskin maapohjaisia lattioita esiintyy runsaasti etenkin ensimmäisessä luokassa. Puu on yleisin kotieläinrakennusten laipioitten rakennusaine, mutta betonisiakin on runsaasti. Myös kotieläinrakennusten katot ovat pääasiallisesti päreestä.

Varastojen seinät ja lattiat ovat lähes yksinomaan puuta. Lauta on ollut yleisempi rakennusaine kuin hirsi. Tutkituilla viljelmillä ei ollut yhtään 1950-luvulla rakennettua hirsistä varastorakennusta. Varastojen kattamisaineena päre on vielä yleisempi kuin asuin- ja kotieläinrakennusten kattamisaineena. 


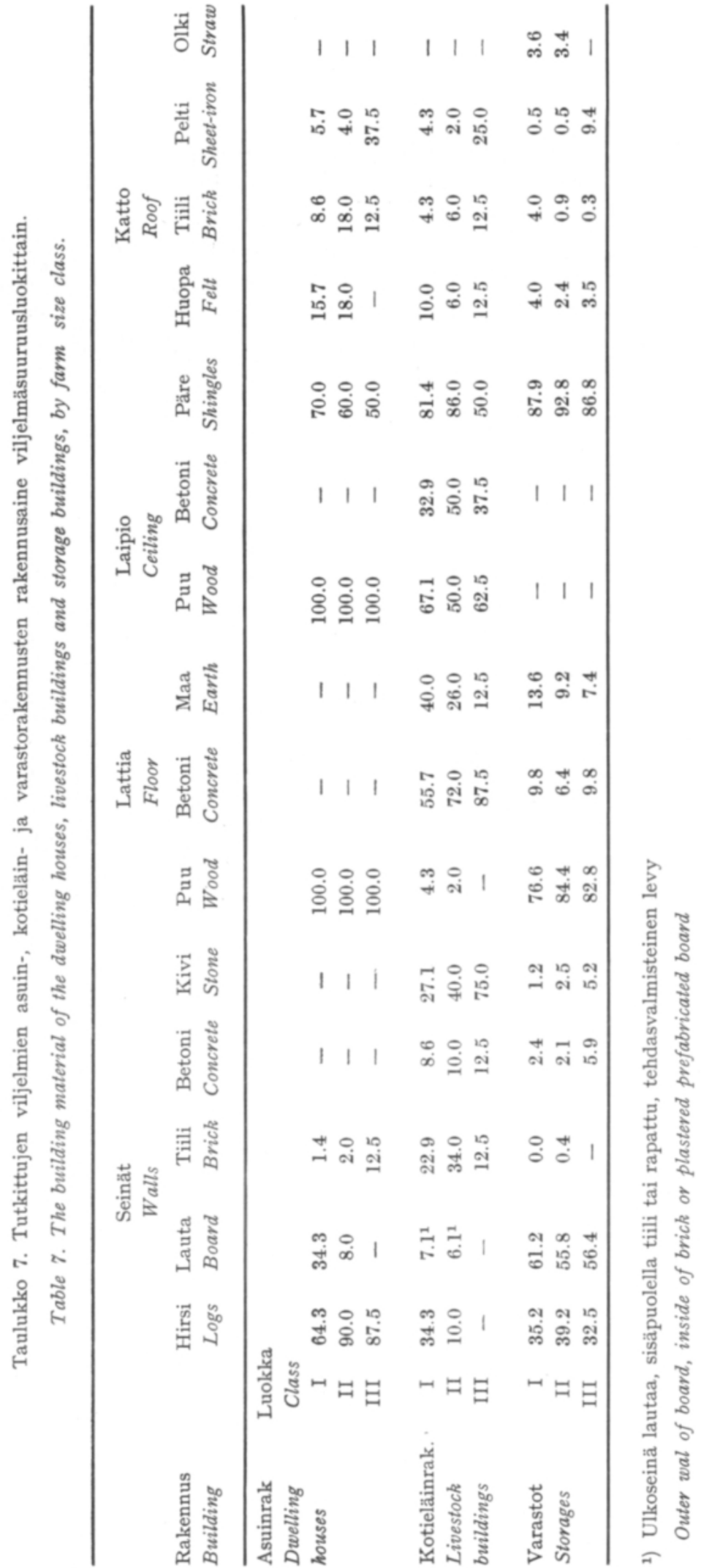




\section{Rakennusten arvo}

Rakennusten arvo on määritetty sivuilla 17 ja 18 esitetyllä tavalla. Tutkituilla viljelmillä oli rakennettu 1950-luvun lopulla 9 kotieläin- ja 6 asuinrakennusta, joista oli käytettävänä yksityiskohtaiset kustannusarviot. Mainittujen rakennusten kustannusarvioita on verrattu niiden tilavuuden ja kuutiohintojen perusteella laskettuun arvoon. Tulokset osoittivat, että uusia rakennuksia arvioitaessa kuutiohintojen mukaan laskettu rakennusten keskimääräinen arvo oli 87.8 \% kustannusarviosta. Kuutiohintojen mukaan laskettu asuinrakennusten arvo oli $84.9 \%$ ja kotieläinrakennusten arvo $91.5 \%$ kustannusarviosta. Koko aineistolle laskettu variaatiokerroinprosentti oli 14.9.

Kustannusarvioissa puutavara oli hinnoitettu sen mukaan, mitä siitä olisi pitänyt maksaa, jos se olisi ostettu paikkakunnan sahoilta. Viljelijäväestö saa puutavaran pääasiallisesti omasta metsästään ja käyttää omiin tarkoituksiin halvimman puutavaran. Kun sahaus suoritetaan usein kotona, jäävät kuljetuskustannukset vähäisiksi. Näistä syistä omasta metsästä otetusta puutavarasta aiheutuvat kustannukset, kantoraha mukaanluettuna, jäävät pienemmiksi kuin kustannusarvioon merkitty summa osoittaa. Lisäksi maaseudulla saataneen osa rakennustyövoimasta halvemmalla kuin kustannusarvioissa käytetty yksikköhinta edellyttäisi.

Koska näyttää, että maatalousrakennusten laskettu kustannusarvio on korkeampi kuin todelliset kustannukset, on ArOLAN (1) esittämiä yksikköhintoja käytetty rakennusomaisuuden arvoa laskettaessa sellaisina, kuin hän ne esittää kuitenkin sillä poikkeuksella, että niihin on tehty Pellervo-Seuran laatiman rakennustarvikeindeksin mukainen korjaus.

\section{Rakennusten jälleenhankinta-arvo}

Taulukoissa 8 ja 9 on esitetty rakennusomaisuuden jälleenhankinta-arvo viljelmäsuuruusluokittain.

Asunnon keskimääräinen jälleenhankinta-arvo on tutkituilla viljelmillä II:ssa viljelmäsuuruusluokassa noin 1.5 kertaa ja III:ssa viljelmäsuuruusluokassa noin 2.9

Taulukko 8. Rakennusomaisuuden jälleenhankinta-arvo $\mathrm{mk} /$ viljelmä tutkituilla viljelmillä vuonna 1960 viljelmäsuuruusluokittain.

Table 8. The replacement value of the buildings, marks per hectare, on the farms investigated in 1960 , by farm size class.

\begin{tabular}{rcccccc}
\hline $\begin{array}{c}\text { Suuruus- } \\
\text { luokka } \\
\begin{array}{c}\text { Size } \\
\text { class }\end{array}\end{array}$ & $\begin{array}{c}\text { Asuin- } \\
\text { rakennus } \\
\text { Dwelling } \\
\text { house }\end{array}$ & Sauna & $\begin{array}{c}\text { Kotieläin- } \\
\text { rakennus } \\
\text { Livestock } \\
\text { building }\end{array}$ & $\begin{array}{c}\text { Korsirehu- } \\
\text { varastot } \\
\text { Straw feed } \\
\text { storages }\end{array}$ & $\begin{array}{c}\text { Mut matal. } \\
\text { rak. }\end{array}$ & Yhteensä farm \\
building & Total \\
\hline I & 9757 & 1149 & 5758 & 3080 & 2382 & 22126 \\
II & 14496 & 1389 & 11705 & 7107 & 4787 & 39484 \\
III & 27984 & 2826 & 29516 & 15131 & 16593 & 92050
\end{tabular}


Taulukko 9. Rakennusomaisuuden jälleenhankinta-arvo mk/ha tutkituilla viljelmillä v. 1960 viljelmäsuuruusluokittain.

Table 9. The replacement value of the buildings, marks per hectare, on the farm investigated in 1960, by farm size class.

\begin{tabular}{|c|c|c|c|c|c|c|}
\hline $\begin{array}{c}\text { Suuruus- } \\
\text { luokka } \\
\text { Size } \\
\text { class }\end{array}$ & $\begin{array}{l}\text { Asuin- } \\
\text { rakennus } \\
\text { Dwelling } \\
\text { house }\end{array}$ & Sauna & $\begin{array}{c}\text { Kotieläin- } \\
\text { rakennus } \\
\text { Livestock } \\
\text { building }\end{array}$ & $\begin{array}{l}\text { Korsirehu- } \\
\text { varastot } \\
\text { Straw feed } \\
\text { storages }\end{array}$ & $\begin{array}{c}\text { Muut maatal. } \\
\text { rak. } \\
\text { Other farm } \\
\text { building }\end{array}$ & Yhteensä \\
\hline I & 1640 & 188 & 964 & 518 & 400 & 3700 \\
\hline II & 1056 & 101 & 853 & 518 & 349 & 2877 \\
\hline III & 730 & 74 & 770 & 395 & 433 & 2402 \\
\hline
\end{tabular}

kertaa suurempi kuin I:ssa viljelmäsuuruusluokassa. Peltohehtaaria kohti asunnon jälleenhankinta-arvo on päinvastainen. Se on II:ssa luokassa 1.4 kertaa ja I luokassa 2.3 kertaa suurempi kuin III:ssa luokassa.

Asuinrakennusten jälleenhankinta-arvo viljelmällä asuvaa viljelijäperheen jäsentä ja viljelmällä vakinaisesti työskentelevän ja asuvan palkatun työntekijän perheenjäsentä kohti oli tutkituilla viljelmillä keskimäärin seuraava:

$\begin{array}{ccc}\begin{array}{c}\text { Viljelmä- } \\ \text { suuruusluokka }\end{array} & \begin{array}{c}\text { Rak.arvo } \\ \text { mk/henkilö }\end{array} & \text { Suhdeluku } \\ \text { I } & 2483 & 100 \\ \text { II } & 3084 & 124 \\ \text { III } & 4277 & 172\end{array}$

Viljelmän koon lisääntyessä on voitu rakentaa sekä suurempia että parempia asuntoja. Vaikka samaa teknillistä tasoa olevalle suurelle asunnolle on käytetty huomattavasti alempia yksikköhintoja kuin pienelle asunnolle, on keskimääräiseksi kuutiometrin jälleenhankinta-arvoksi saatu ensimmäisessä viljelmäsuuruusluokassa $43 \mathrm{mk}$ ja toisessa ja kolmannessa $42 \mathrm{mk}$. Tämä aiheutuu siitä, että toisen ja kolmannen suuruusluokan viljelmien asuntojen teknillinen taso on ollut huomattavasti korkeampi kuin ensimmäiseen suuruusluokkaan kuuluvien asuntojen teknillinen taso.

Talousrakennusten (ei asuinrakennus ja sauna) jälleenhankinta-arvo muunnettua peltohehtaaria kohti oli tutkituilla viljelmillä seuraava:

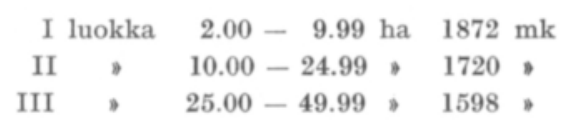

Yllä käytetty viljelmäsuuruusluokkien luokkaväli on ilmeisesti rakennusten keskimääräistä arvoa ilmaistaessa liian suuri. Aikaisemmin rakennusten määrää tarkasteltaessa havaittiin, että harva luokkajaoitus antoi pienimpien viljelmien kohdalta erheellisen kuvan. Kuvioon 5 on piirretty kaksi tutkittujen viljelmien talousrakennusten jälleenhankinta-arvoa esittävää kuvaajaa. Toinen käyrä kuvaa rakennusten arvoa, joka on saatu luokittelemalla tutkimusaineisto kolmeen luok- 


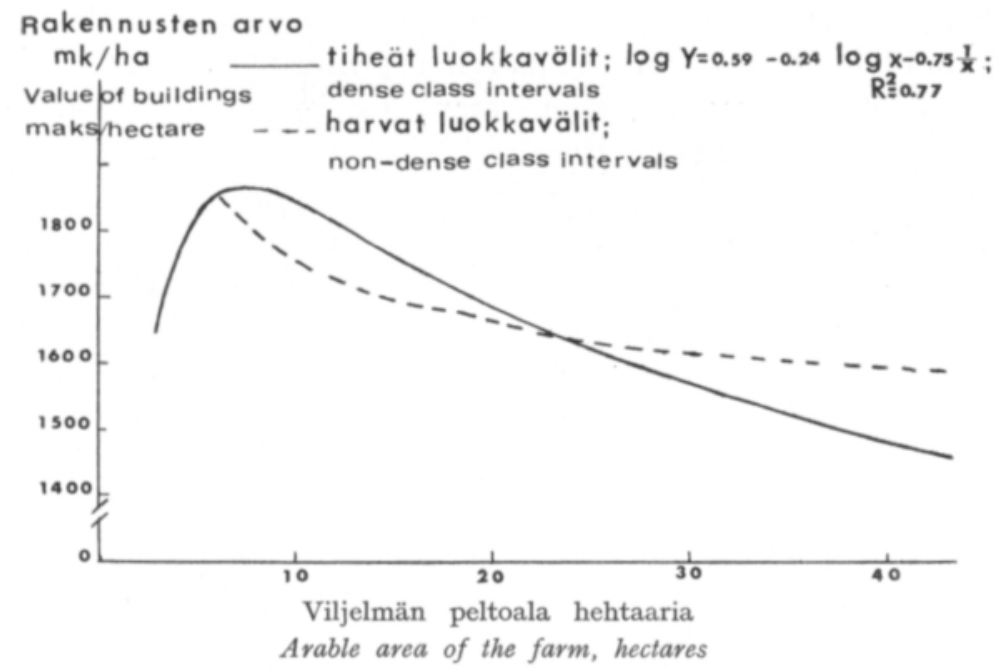

Kuvio 5. Talousrakennusten jälleenhankinta-arvo tutkituilla viljelmillä.

Fig. 5. Replacement value of the outhouses on the farms investigated.

kaan kuten yllä on esitetty. Toinen käyrä taas kuvaa kuviossa 1 käytetyin, lyhyin luokkavälein laskettujen keskiarvojen avulla muodostettua funktiota. Talousrakennusten jälleenhankinta-arvo hehtaaria kohti saavuttaa tutkituilla viljelmillä korkeimman arvon noin 7 peltohehtaarin viljelmillä ja laskee tämän jälkeen lähes lineaarisesti viljelmän peltoalan lisääntyessä.

Eri rakennusten tai rakennusryhmien prosenttinen osuus koko viljelmän rakennusomaisuuden jälleenhankinta-arvosta on esitetty alla olevassa asetelmassa.

\begin{tabular}{lrrr} 
& \multicolumn{4}{c}{ V i l j e l m ä s u r u u s l u o k a t } \\
Rakennus tai rakennusryhmä & I & II & III \\
Asuinrakennus & 44.1 & 36.7 & 30.4 \\
Sauna & 5.2 & 3.5 & 3.1 \\
Kotieläinrakennukset & 26.0 & 29.7 & 32.1 \\
Korsirehuvarastot & 13.9 & 18.0 & 16.4 \\
Muut rakennukset & 10.8 & 12.1 & 18.0
\end{tabular}

Jos talousrakennuksiin luetaan kaikki muut rakennukset paitsi asuinrakennus ja sauna, tulee talousrakennusten osuudeksi koko viljelmän rakennusomaisuudesta ensimmäisessä luokassa $50.7 \%$, toisessa luokassa $59.8 \%$ ja kolmannessa luokassa $66.5 \%$. Talousrakennusten yhteisestä arvosta kotieläinrakennusten osuus on ensimmäisessä luokassa $51.3 \%$, toisessa luokassa $49.7 \%$ ja kolmannessa luokassa $48.3 \%$.

\section{Rakennusten nykyarvo}

Vaikka maatalousrakennusten jälleenhankinta-arvo pystyttäneenkin arvioimaan riittävän tarkasti, tuottaa niiden nykyarvon määritys verraten suuria vaikeuksia. Maatalousrakennusten ja erikoisesti tuotantotoimintaan käytettyjen 
talousrakennusten nykyarvo ei ole riippuvainen ainoastaan niiden teknillisestä kunnosta, vaan huomattavan suuressa määrin rakennusten sopivuudesta viljelmällä nykyisin harjoitettavaan tuotantotoimintaan. Jos rakennus on esim. liian suuri, jää siitä osa tyhjäksi. Tyhjäksi jäävä tila voi olla täysin arvotonta. Joissakin tapauksissa se voi aiheuttaa jopa negatiivisia vaikutuksia kunnossapitokustannuksina ja työnmenekin lisääntymisenä. Niissä tapauksissa, joissa tutkitun viljelmän rakennukset olivat kohtuuttoman suuret nykyiseen tarpeeseen verrattuna, viljelmän talousrakennusten alasta tai tilavuudesta on rakennusten arvoa laskettaessa otettu huomioon vain se osa, joka oli arviohetkellä viljelmän peltoalan hyväksikäyttämiseksi paikkakunnalla vallitsevan tuotantosuunnan mukaan tarpeen. Rakennusten muusta kuin liiasta tilavuudesta aiheutuva epätarkoituksenmukaisuus on otettu huomioon kuntoisuuslukua määritettäessä, kuten edellä olevasta osasta »käytetyt arviointimenetelmät» käy ilmi. Tutkittujen viljelmien rakennusomaisuuden nykyarvo käy ilmi taulukoista 10 ja 11 .

Rakennusten keskimääräinen nykyarvo hehtaaria kohti Sisä-Suomen kirjanpitoviljelmillä, jotka sekä sijaintinsa että niillä harjoitetun tuotannon puolesta muistuttavat läheisesti tutkittuja viljelmiä, oli tilivuonna 1959/60 seuraava:

\begin{tabular}{|c|c|c|c|}
\hline Rakennusryhmä & I & II & III \\
\hline Asuinrak. & $1030 \mathrm{mk}$ & $666 \mathrm{mk}$ & $643 \mathrm{mk}$ \\
\hline Eläinsuojat & 869 & 547 & 452 \\
\hline Muut rak. & 577 & 456 & 363 \\
\hline
\end{tabular}

Ensimmäisessä suuruusluokassa kirjanpitoviljelmien rakennusten arvo hehtaaria kohti on ollut $6.5 \%$ ja toisessa luokassa $3.7 \%$ alhaisempi kuin tutkittujen viljelmien rakennusten nykyarvo, mutta kolmannessa luokassa kirjanpitoviljelmien rakennusten arvo on ollut $19.5 \%$ tutkittujen viljelmien rakennusten arvoa korkeampi. Tämän suuruiset erot saattavat aiheutua jo arviointiperusteiden erosta. Rakennuskuutiometrin jälleenhankinta-arvo voi eri arvioissa hieman poiketa ja aiheuttaa mainitun suuruisen eron. Tutkittujen ja kirjanpitoviljelmien rakennus-

Taulukko 10. Rakennusomaisuuden nykyarvo mk/viljelmä tutkituilla viljelmillä vuonna 1960 viljelmäsuuruusluokittain.

Table 10. The present value of the buildings, marks per farm, on the farm investigated in 1960, by farm size class.

\begin{tabular}{ccccccc}
\hline $\begin{array}{c}\text { Suuruus- } \\
\text { luokka } \\
\text { Size } \\
\text { class }\end{array}$ & $\begin{array}{c}\text { Asuin- } \\
\text { rakennus } \\
\text { Dwelling } \\
\text { house }\end{array}$ & Sauna & $\begin{array}{c}\text { Kotieläin- } \\
\text { rakennus } \\
\text { Livestock } \\
\text { building }\end{array}$ & $\begin{array}{c}\text { Korsirehu- } \\
\text { varastot } \\
\text { Straw feed } \\
\text { storages }\end{array}$ & $\begin{array}{c}\text { Mut maatal. } \\
\text { rak. }\end{array}$ & Yhteensä farm \\
building & Total \\
\hline I & 7371 & 787 & 3898 & 2160 & 1638 & 15854 \\
II & 8491 & 851 & 7320 & 4445 & 2663 & 23770 \\
III & 11558 & 1833 & 15079 & 8525 & 9765 & 46760
\end{tabular}


Taulukko 11. Rakennusomaisuuden nykyarvo mk/ha tutkituilla viljelmillä vuonna 1960 viljelmäsuuruusluokittain.

Table 11. The present value of the buildings, marks per hectare, on the farms investigated in 1960, by farm size class.

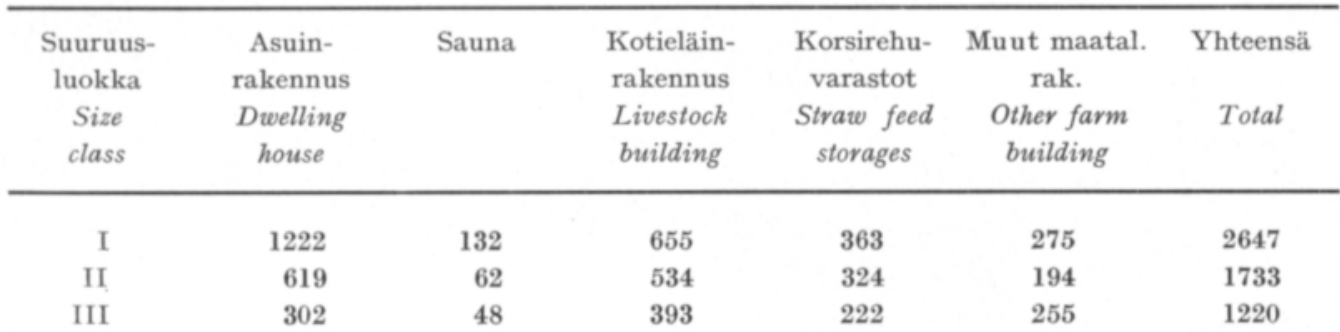

omaisuuden arvon ero voisi osaksi johtua myös tutkitun aineiston ikärakenteesta. Tutkittujen pienten viljelmien rakennukset olivat keskimäärin varsin nuoria ja suurten viljelmien verraten vanhoja. Sisä-Suomen kirjanpitoviljelmien rakennusten ikärakenne tuskin on samanlainen. On luultavaa, että pienten viljelmien rakennukset ovat Sisä-Suomessa itäisintä osaa lukuunottamatta vanhempia kuin tutkitut rakennukset. Näin ollen myös niiden nykyarvo lienee pienempi kuin tutkituilla viljelmillä. Tutkimusaineiston III suuruusluokan viljelmien rakennukset taas lienevät vanhempia kuin samansuuruisten kirjanpitoviljelmien rakennukset.

Rakennusomaisuuden nykyarvon suhde eri viljelmäsuuruusluokkien välillä ei ole sama kuin jälleenhankinta-arvon suhde. Eri suuruusluokissa rakennusten ikä vaihtelee huomattavasti. Kuten rakennusten ikää koskettelevassa osassa todettiin, on pienimpien viljelmien rakennukset huomattavan suurelta osalta rakennettu viimeisten sotien jälkeen. Ensimmäisen suuruusluokan viljelmillä rakennusten nykyarvo on arvioitu 71.7 prosentiksi niiden jälleenhankinta-arvosta. Toisessa viljelmäsuuruusluokassa rakennusten nykyarvo on arvioitu 60.2 prosentiksi ja kolmannessa suuruusluokassa 50.8 prosentiksi. Asuinrakennusten nykyarvo on ensimmäisessä luokassa $75.5 \%$, mutta kolmannessa ainoastaan $41.3 \%$. Taulukosta 6 voidaan havaita, että asuinrakennusten keski-ikä ensimmäisessä luokassa on ollut 21 vuotta, mutta kolmannessa 53 vuotta. Holmsтröм $(8$, s. 12) on arvioinut, että Ruotsissa maatalouden talousrakennusten nykyarvo vuonna 1954 olisi ollut $64.6 \%$ jälleenhankinta-arvosta.

\section{Talousrakennusten kapasiteetin hyväksikäyttö tutkituilla viljelmillä}

Edellä on tarkasteltu kotieläinrakennusten alaa ja varastorakennusten tilavuutta sekä eri rakennusryhmien arvoa. Rakennusten määrän lisäys tutkituilla viljelmillä ei ollut, kuten edellä todettiin, suorassa suhteessa peltoalan lisäykseen, vaan rakennusten määrä lisääntyi hitaammin kuin peltoala. Tämä on yleisesti tunnettu ja todettu myös mm. seuraavissa tutkimuksissa: Tutkimuksia Suomen maatalouden kannattavuudesta (27), MäKI (17. s. 51), SiPILÄ (22, s. 28). Mutta myös saman kokoisilla viljelmillä rakennusten määrä vaihtelee huomattavasti (taulukko 5 ja 
kuvio 4). Viljelmällä tarvittavien rakennusten määrään vaikuttavista tekijöistä peltoala on se, joka satotaso huomioon ottaen säätelee yleensä ne puitteet, missä viljelmän talousrakennusten rakennustarve voi liikkua.

Viljelijän valitsema tuotantosuunta ja valitun tuotannon laajuus määräävät taas, mitä rakennuksia ja kuinka paljon yritys tulee tarvitsemaan. Niinpä kotieläinrakennustilan tarve riippuu kotieläinlajista ja kotieläinten määrästä. Kun maassamme kotieläinten ruokinta perustuu lähes yksinomaan kotoisiin rehuihin, viljelmältä saatavien rehujen määrä asettaa eräitä poikkeuksia lukuunottamatta pidettävien eläinten määrälle ylärajan ja samalla rajan myös kotieläinrakennusten ja rehuvarastojen maksimitarpeelle. Luonnon oloista, yrittäjän kiinnostuksesta tiettyjä tuotannonhaaroja kohtaan ja tuotannonhaarojen keskimääräisestä kilpailukyvystä riippuu suurelta osalta, mitkä tuotannonhaarat ja missä laajuudessa viljelijä valitsee. Kun nämä on valittu ja tavoitteena oleva intenssiteetti määritetty, voidaan hahmotella viljelmän talousrakennusten tarve.

Rakennusten kestoaika on yleensä pitkä. Puiset rakennukset ovat käyttökelpoisia 1-2 sukupolven ajan ja kivirakenteiset kestävät vieläkin kauemmin. Kunkin sukupolven aikana ja erityisesti sukupolvien vaihtuessa viljelmän rakenteessa ja myös tuotantosuunnassa tapahtuu muutoksia. Viljelmä voidaan jakaa sisarusten kesken tai siihen yhdistetään uusia alueita, karjataloudesta siirrytään karjattomaan talouteen, lypsykarjan hoidosta sikojen kasvatukseen jne. Osa vanhoista rakennuksista ehkä voidaan käyttää hyväksi tuotantosuunnan muutoksista huolimatta ja osa mukauttaa uusia oloja vastaaviksi, mutta rakennustilaa voi olla liikaa ja usein vanhat rakennukset ovat epäkäytännöllisiä.

Tutkimusaineistoon kuuluvilta 129:1tä viljelmältä on tässä yhteydessä selvitetty, missä määrin näillä viljelmillä käytettiin tutkimusvuonna hyväksi kotieläinrakennusten ja korsirehuvarastojen kapasiteettia. Rakennusten kapasiteetin hyväksikäyttöä selvitettäessä on laskettu, kuinka suuri oli tutkittujen viljelmien kotieläinrakennusten ja korsirehuvarastojen tarve tutkimushetkellä. Kapasiteetin hyväksikäyttö on ilmaistu lasketun rakennustarpeen ja viljelmällä tutkimushetkellä olleen rakennusten määrän suhteena.

\section{Kotieläinrakennukset}

Rakennusaineistoa koottaessa ei tiedusteltu, kuinka monta lehmää, hiehoa, vasikkaa, hevosta tai muuta kotieläintä voidaan sijoittaa kotieläinrakennusten parsiin tai karsinoihin. Tutkimusaineistosta ei voida näin ollen laskea, kuinka suuri osa parsista ja karsinapaikoista kotieläinrakennusten nykyisen sisustuksen mukaan oli käytetty hyväksi. Jos rakennuksen kapasiteetti olisi laskettu suunniteltujen parsien ja karsinapaikkojen mukaan, voitaisiin kyllä laskea, kuinka suuri osa näin lasketusta kapasiteetista oli tutkimushetkellä käytetty hyväksi. Näin selvitettäisiin viime kädessä nykyisen viljelijän tämän hetkisen sisustuksen mukainen kapasiteetin hyväksikäyttö. Kotieläinrakennuksen lämpimän alan tarkoituksenmukaista suunnittelua nykyiseen käyttöön se ei ilmaisisi. Kun kotieläinrakennuksen parsien, karsinoìden, käytävien ja muiden aputilojen sijoittelu vaikuttaa aivan oleellisesti koko lämpimän alan hyväksikäyttöön, on tässä yhteydessä laskettu, kuinka paljon 
lämmintä kotieläinrakennusalaa on ollut eri viljelmillä nautayksikköä kohti ja millainen suhde vallitsee viljelmällä laskelmien mukaan tarvittavan ja viljelmällä olevan kotieläinrakennusalan kesken.

Nautayksiköiden luku on laskettu ottamalla huomioon eri eläinlajien ja eriikäisten eläinten rakennusalan tarve. Nautayksiköiksi muuntaminen on suoritettu seuraavasti:

Yhtä nautayksikköä vastaa:

1 lehmä tai sonni,

2/3 täysikasvuista hevosta,

1 nuori hevonen tai varsa,

2 hiehoa tai vasikkaa,

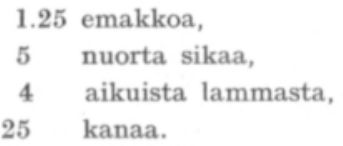

Ruotsalaisten maatalouden rakennusasiantuntijain mietinnössä (10, s. 84) on käytetty ny:n asemesta käsitettä »kreaturplats», jolle mahtuu 1 lehmä tai sonni, 2 hiehoa tai vasikkaa, $2 / 3$ hevosta, $3 / 2$ varsaa tai nuorta hevosta, 5 porsasta, 10/3 lammasta tai 20 kanaa. Møller $(18$, s. 81) käyttää muuten samoja muuntolukuja kuin yllä, mutta 1 hevonen on 1.67 ny:tä ja 1 hieho 0.6 ny:tä.

Nautayksikön tarvitsema lattia-ala vaihtelee hieman rakennuksen koon mukaan. Siihen vaikuttaa myös, ovatko eläimet kytkettyinä tai irrallaan. Käsiteltävään tutkimusaineistoon kuului 5 pihattonavettaa ja 122 parsinavettaa, joten seuraavassa kosketellaan nautayksikön rakennustarvetta lähinnä parsityyppisissä navetoissa. ASO:n rakennustoimiston julkaisun $(16$, s. 11) mukaan ny:n vaatima lämmin lattiaala on noin $6.25 \mathrm{~m}^{2} / \mathrm{ny}$. Navettatoimikunnan mietinnössä $(11, \mathrm{~s}$. 34) eri eläinten vaatima lattia-ala on esitetty eläintä kohti ilman käytäviä. Käytävien alaksi on arvioitu $43 \%$ eläinten tarvitsemasta alasta. Esitetyssä esimerkissä (s. 36) tulee lattia-alaa ny:tä kohti $6.5 \mathrm{~m}^{2}$. Tässä ei ole mukana karjakeittiötä. Pihaton alaksi sama toimikunta on saanut tutkimuksissaan $6.2 \mathrm{~m}^{2}$ eläintä kohti $(19, \mathrm{~s} .61)$.

HJElm (6, s. 423) ja SköLdENBERG (25, s. 263) esittävät, että parsisysteemiä käytettäessä tarvitaan $6-7 \mathrm{~m}^{2}$ lattia-alaa täysikasvuista nautaeläintä kohti, mutta pihatossa on lattia-alan tarve $8-10 \mathrm{~m}^{2}$.

Käsillä olevassa tutkimuksessa kotieläinrakennusten lämpimään alaan on luettu varsinaisen eläimille varatun alan lisäksi myös karjakeittiön, maitohuoneen, mikäli se on ollut lämpimien seinien sisällä ja lämpimien komeroiden ala. Mitä pienemmälle eläinmäärälle rakennus on tehty, suhteellisesti sitä suurempi osa sen alasta tarvitaan karjakeittiölle aputiloineen. Yhdelle nautayksikölle tarvittava ala on tässä laskettu siten, että perustana on pidetty $6.5 \mathrm{~m}^{2} / \mathrm{ny}$. Tähän on lisätty alle $50 \mathrm{~m}^{2}$ kotieläinrakennuksissa, joissa on ollut karjakeittiö $2.0 \mathrm{~m}^{2} /$ ny karjakeittiötä ja muita tähän liittyviä aputiloja varten. Rakennuksen ollessa $50 \mathrm{~m}^{2}$ tai yli on karjakeittiötä ja aputiloja varten laskettu $1.5 \mathrm{~m}^{2} /$ ny. Näin laskien tulisi pieneen kotieläinrakennukseen, jossa lehmät ovat kytkettyinä, voida sijoittaa 1 nautayksikkö $8.5 \mathrm{~m}^{2}$ kohti ja suuremmissa rakennuksissa 1 nautayksikkö $8.0 \mathrm{~m}^{2}$ kohti. Pihatossa tarvittavaksi lattia-alaksi lypsypaikkoineen ja karjakeittiöineen on laskettu $10 \mathrm{~m}^{2} / \mathrm{ny}$. Kirjoittaja haluaa tässä yhteydessä huomauttaa, että edellä esitetty ny:tä kohti tarvittava lattia-ala ja sen laskentamenetelmä saattaa poiketa huomattavasti rakennusammattimiehen näkemyksestä. Tässähän ny:n tarvitsemaan alaan on otettu myös karja- 
keittiön, maitohuoneen ja lämpimien komeroiden ala. Voi tuntua, että tämä sotkee kapasiteetin hyväksikäytön laskentaa. Karjakeittiön, maitohuoneen ja muiden aputilojen alan tarvehan riippuu paitsi nautayksiköiden luvusta myös eläinlajista, tuotantosuunnasta ja hoito- ja ruokintamenetelmästä. Tutkimusalueella kotieläintuotanto on melkein yksinomaan maidontuotantoa ja siihen sivutuotteena liittyvän naudanlihan tuotantoa. Tutkittujen viljelmien nautayksiköiden luvusta oli ainoastaan $11.9 \%$ sikoja ja lampaita. Jokaisella tutkitulla viljelmällä, jolla oli kotieläimiä, oli myös lehmiä. Tuotanto on siis hyvin suuressa määrin samanlaista. Myös rakennusten ja aputilojen tarve eri viljelmillä täytyy näin ollen olla samanlaista. Hoitoja ruokintamenetelmät ovat tutkimusalueella sangen yhtenäiset. Pihattoja oli $3.9 \%$ navettojen ja yhdistettyjen kotieläinrakennusten luvusta. Muissa tapauksissa nautakarja pidettiin kytkettynä. Hyvin pienissä kotieläinrakennuksissa ei ollut karjakeittiötä. Tällöin ny:n tarvitsemaksi alaksi on laskettu $6.5 \mathrm{~m}^{2}$. Vaikka tässä esitettävä kapasiteetin hyväksikäyttö absoluuttisina yksiköinä tarkasteltaessa ei lienekään paras mahdollinen, tulokset suhdelukuina osoittavat selvästi kapasiteetin hyväksikäytön laajan vaihtelun.

Kotieläinrakennusten ala nautayksikköä kohti on ollut pienin 2-3.99 hehtaarin viljelmillä (kuvio 6). Viljelmän koon lisääntyessä aluksi rakennusala/ny kasvaa,

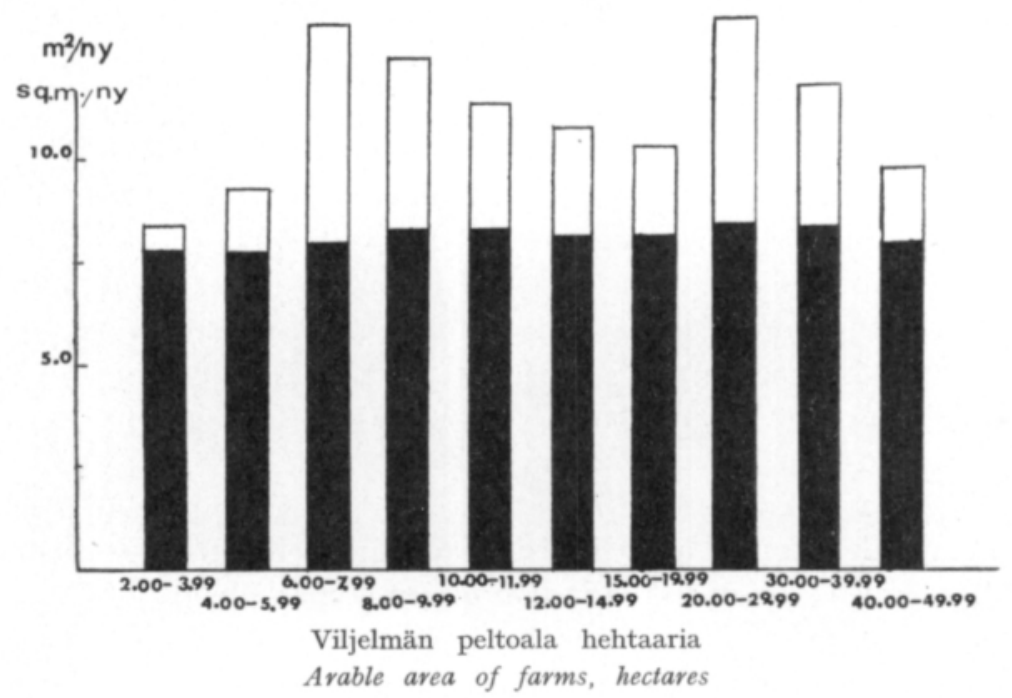

Kuvio 6. Kotieläinrakennusten ala $\mathrm{m}^{2} / \mathrm{ny}$ (koko pylväs) ja kotieläinrakennusten tarve $\mathrm{m}^{2} / \mathrm{ny}$ (pylvään musta osa) tutkituilla viljelmillä.

Fig. 6. Area of livestock buildings, sq.m./livestock unit (whole column) and the need of livestock buildings sq.m./livestock unit (the black part of the column).

mutta se alkaa supistua jo luokasta $6-7.99$ ha. Supistumista jatkuu kahta viimeisen edellistä luokkaa lukuunottamatta. Kun keskimääräinen nautayksikön tarvitsema ala tässä käytetyin laskentaperustein vaihtelee vähän, jää hyväksikäyttämätöntä rakennusalaa eniten siellä, missä rakennusala ny:tä kohti on ollut suurin. Kuviosta 1 voidaan havaita, että peltohehtaaria kohti lasketusta ohjeellisesta rakennusalasta 
poikkeaa emppiirinen aineisto eniten $7-20$ peltohehtaarin viljelmillä. Näillä viljelmillä on myös ny:tä kohti eniten rakennusalaa. Poikkeuksen tekivät ainoastaan 20-39.99 hehtaarin luokkiin kuuluvat viljelmät, joiden kohtuuttoman suuri rakennusala ny:tä kohti aiheutuu siitä, että eräillä viljelmillä kotieläinten luku on supistettu vähäiseksi.

Kotieläinrakennusten hyväksikäyttö vaihtelee yksityisissä tapauksissa enemmän kuin ryhmittäin tarkasteltuna. Taulukossa 12 tutkimusaineisto on ryhmitetty sen mukaan, kuinka monta \% viljelmän kotieläinrakennusten maksimikapasiteetista oli tutkimushetkellä käytetty hyväksi. Tässä on käytetty samaa viljelmäsuuruusluokittelua kuin kannattavuustutkimuksessa.

Eräillä pienillä viljemillä kotieläinrakennukset olivat puutteellisia. Mutta vaikka näitä ei otettaisikaan huomioon, on tutkimusaineistosta selvästi havaittavissa, että monella viljelmällä kotieläinrakennus oli niin suunniteltu ja hyväksikäytetty, että lämmintä alaa on tarvittu verraten vähän ny:tä kohti. Kaikista viljelmistä $30.2 \%$ käytti tutkimushetkellä $90 \%$ tai enemmän hyväksi kotieläinrakennuksen lasketusta maksimikapasiteetista. Näillä viljelmillä käytettiin keskimäärin $7.7 \mathrm{~m}^{2}$ lämmintä alaa ny:tä kohti. Tähän ryhmään kuuluu 17 sellaista kotieläinrakennusta, joissa ei ollut karjakeittiötä. Näiden keskimääräinen lämmin lattia-ala oli $6.5 \mathrm{~m}^{2} / \mathrm{ny}$. Karjakeittiöllä varustettujen kotieläinrakennusten $(21 \mathrm{kpl})$, joiden kapasiteetista käytettiin yli $90 \%$ hyväksi, ala ny:tä kohti oli $8.0 \mathrm{~m}^{2}$. Yhdellätoista viljelmällä $(15 \%)$ kotieläinrakennusten lasketusta maksimikapasiteetista käytettiin hyväksi vähemmän kuin $50 \%$.

WESTERMARCK $(28$, s. 93) on kanataloustyön taloudellista merkitystä koskevassa tutkimuksessaan osoittanut, että kanatalousrakennuksiin kanaa kohti käytetty pääoma vaihtelee hyvin suuresti eri viljelmillä.

Taulukko 12. Tutkittujen kotieläinrakennusten jakaantuminen viljelmäsuuruusluokittain ryhmiin kotieläinrakennuksen kapasiteetin hyväksikäytön mukaan.

Table 12. The distribution by farm size class of the livestock buildings into groups according to utilisation of capacity.

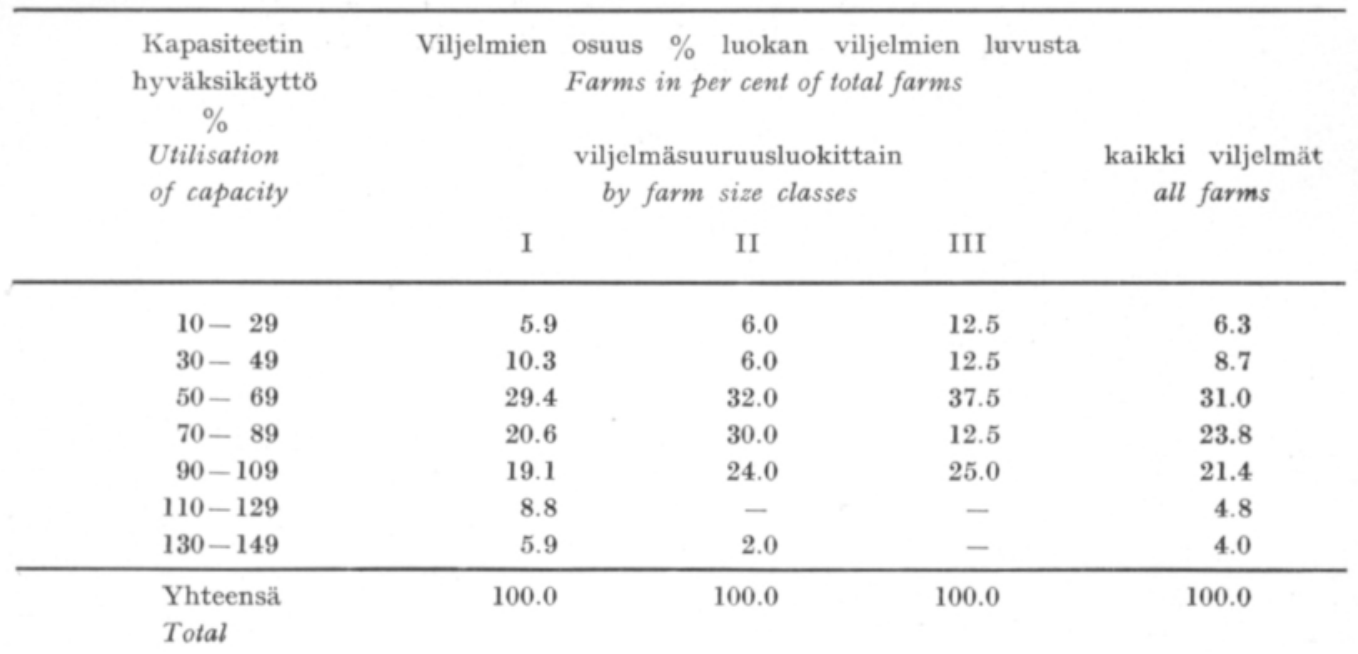


Taulukko 13. Eri ikäisten kotieläinrakennusten jakaantuminen ryhmiin kapasiteetin hyväksikäytön mukaan.

Table 13. Distribution of livestock buildings of different ages into groups by the utilisation of capacity.

\begin{tabular}{|c|c|c|c|c|c|c|c|}
\hline \multirow{3}{*}{$\begin{array}{c}\text { Rakennusten ikä } \\
\text { vuotta } \\
\text { Age of the } \\
\text { buildings } \\
\text { years }\end{array}$} & \multicolumn{6}{|c|}{$\begin{array}{c}\text { Rakennusken kapasiteetista käytetty hyväksi \% } \\
\text { Percentage of building capacity utilised }\end{array}$} & \multirow{3}{*}{$130-149$} \\
\hline & $10-29$ & $30-49$ & $50-69$ & $70-89$ & $90-109$ & $110-129$ & \\
\hline & \multicolumn{6}{|c|}{$\begin{array}{l}\text { Kotieläinrakennusten luku } \\
\text { Number of livestock buildings }\end{array}$} & \\
\hline alle 10 & - & 2 & 19 & 7 & 10 & 3 & - \\
\hline $10-19$ & 1 & 3 & 4 & 8 & 8 & 2 & 1 \\
\hline $20-29$ & - & - & 5 & 8 & 3 & 1 & 2 \\
\hline $30-39$ & 3 & 2 & 3 & 2 & 3 & & 1 \\
\hline $40-49$ & 1 & 1 & 3 & 3 & 1 & & 1 \\
\hline $50-59$ & - & - & 2 & 2 & 1 & & \\
\hline $60-69$ & 3 & - & 2 & - & - & & \\
\hline 70 ja yli & - & 2 & 1 & - & 1 & & \\
\hline $\begin{array}{l}\text { Yht. rakenn. } \\
\text { Total of buildi }\end{array}$ & 8 & 11 & 39 & 30 & 27 & 6 & 5 \\
\hline
\end{tabular}

Taulukossa 13 on esitetty eri ikäisten kotieläinrakennusten kapasiteetin hyväksikäyttö tutkimusvuonna. Alle 10 vuotiaita kotieläinrakennuksia oli käytössä 42 . Yhdellä viljelmällä, jolla oli alle 10 vuotta vanha kotieläinrakennus, ei ollut laisinkaan kotieläimiä. Näistä 42 :sta kotieläinrakennuksesta oli 22 selvästi liian suurta viljelmällä tutkimushetkellä pidettävään kotieläinmäärään verrattuna. Nautayksikköä kohti oli näillä viljelmillä lämmintä rakennusalaa keskimäärin $14.2 \mathrm{~m}^{2}$. Kotieläinrakennuksia, joiden ikä oli 10-19 vuotta, oli tutkimuksessa mukana 27 . Näistä kahdeksan kapasiteetista käytettiin hyväksi vähemmän kuin $70 \%$. Ensimmäiseen ja toiseen ikäluokkaan kuuluvista viljelmistä 27 :llä suoritettiin tai ilmoitettiin lähivuosina suoritettavan pellon raivausta. Näiden viljelmien omistajilta tiedusteltiin, kuinka paljon he aikovat lisätä peltoa raivaamalla. Jos näillä viljelmillä lisätään kotieläimiä pellon raivauksen edistyessä samassa suhteessa kuin kotieläimiä vastaavan kokoisilla viljelmillä paikkakunnalla on keskimäärin ollut, muodostuu pellon raivauksen jälkeen kotieläinrakennusten kapasiteetin hyväksikäyttö kahdessa ensimmäisessä ikäluokassa seuraavaksi:

\begin{tabular}{|c|c|c|c|c|c|c|c|}
\hline \multirow[t]{3}{*}{$\begin{array}{l}\text { Rakennuksen } \\
\text { ikä vuotta }\end{array}$} & \multicolumn{7}{|c|}{$\begin{array}{c}\text { Rakennuksen kapasiteetista tullaan käyttämään } \\
\text { hyväksi \% }\end{array}$} \\
\hline & $10-29$ & $30-49$ & $50-69$ & $70-89$ & $90-109$ & $110-129$ & $130-149$ \\
\hline & \multicolumn{7}{|c|}{ Kotieläinrakennsten 1 u k u } \\
\hline alle 10 & - & - & 13 & 10 & 16 & 3 & - \\
\hline $10-19$ & 1 & 2 & 4 & 5 & 12 & 2 & 1 \\
\hline
\end{tabular}

Nuorten kotieläinrakennusten kapasiteetin hyväksikäyttö tulisi paranemaan pellon raivauksen jälkeen. Mutta tällöinkin vielä $29 \%$ alle 20 vuotta vanhoista navetoista olisi sellaisia, joiden maksimikapasiteetista olisi käytetty hyväksi vä- 
hemmän kuin $70 \%$ ja $51 \%$ sellaisia, joiden kapasiteetista olisi käytetty vähemmän kuin $90 \%$. Ainoastaan joka toisen alle 20 vuotiaan kotieläinrakennuksen hyväksikäyttö on niin suunniteltu, että sen kapasiteetista käytetään tai tullaan suunnitelmien mukaan käyttämään enemmän kuin $90 \%$. Kolme alle 20 vuotiasta rakennusta, joiden kapasiteetista käytettiin hyväksi vähemmän kuin $50 \%$, kuuluivat viljelmiin, joilla oli luovuttu lähes kokonaan kotieläinten hoidosta.

Kotieläinrakennusten, joiden ikä on 20 vuotta tai enemmän, hyväksikäyttö on lähes samanlaista kuin 20 vuotta nuorempien rakennusten hyväksikäyttö. Ikäluokassa $20-29$ vuotta vanhat rakennukset kapasiteetista on käytetty hyväksi kaikissa tapauksissa $50 \%$ tai enemmän, mutta $2 / 3$ on sellaisia rakennuksia, joiden kapasiteetista on käytetty hyväksi vähemmän kuin $90 \%$. Kolmekymmenvuotiaitten ja sitä vanhempien rakennusten joukossa on 12 sellaista, joiden kapasiteetista on käytetty hyväksi vähemmän kuin $50 \%$. Näistä neljä kuuluu sellaisiin viljelmiin, jotka joutuivat luovuttamaan peltoa siirtoväelle, 2 kuuluu viljelmiin, jotka on jaettu sisarusten kesken rakentamisen jälkeen ja kuuden viljelmän omistajat ovat vähentäneet viimeisten vuosien aikana huomattavasti kotieläinten määrää.

Kotieläinrakennuksista kuuluu suurin osa luokkiin, joissa kapasiteetin hyväksikäyttö on $50-89 \%$. Näissä luokissa on rakennusalaa $9-17 \mathrm{~m}^{2} / \mathrm{ny}$. Kapasiteetin alhaiseen hyväksikäyttöön näissä tapauksissa lienee osittain vaikuttanut se, että kotieläinrakennukset ovat olleet niin suunniteltuja, ettei niihin ole voitu sijoittaa mainittua enemmän kotieläimiä pinta-alayksikköä kohti. Tätä ei pystytä kerätyn tutkimusaineiston perusteella kuitenkaan tarkastamaan. P ä ä s y y ä u u s i e n kotieläinrakennusten kapasiteetin alhaiseen hyväksikäyttöön lienee rakennusten su unnitteluvaiheessasuoritettu viljelmän rehuntuottokyvyn yliarviointi ja $\mathrm{n}$ a u t a k r a n rehuntarpeen a liarviointi. Tutkituilla viljelmillä oli nautayksiköitä muunnettua peltohehtaaria kohti seuraavasti. (Nautayksiköiden luku laskettu kuten kannattavuustutkimuksen yhteydessä menetellään. Asetelmaan on otettu mukaan myös Sisä-Suomen kirjanpitoviljelmien nautayksiköiden luku):

\begin{tabular}{ccccc}
$\begin{array}{c}\text { Viljelmä- } \\
\text { suuruusluokka }\end{array}$ & $\begin{array}{c}\text { tutkitut } \\
\text { viljelmät }\end{array}$ & \multicolumn{4}{c}{$\begin{array}{c}\text { Nautayksiköitä } 100 \text { ha kohti } \\
\text { kirjanpito- } \\
\text { viljelmät }\end{array}$} \\
I & 86.6 & 120 & 106 & 87.6 \\
II & 73.4 & 95 & 88 & 70.4 \\
III & 45.7 & 87 & 74 & 55.8
\end{tabular}

Tutkittujen viljelmien ny-määrä eri suuruusluokissa on suunnilleen yhtä suuri kuin Sisä-Suomen kirjanpitoviljelmillä tilivuonna 1960/61. Poikkeuksen tekee vain III suuruusluokka.

Sisä-Suomessa ja samoin myös tutkimusalueella ovat nautakarja ja hevoset käyneet metsä- ja hakalaitumilla hyvin huomattavassa määrin aina 1950-luvulle saakka. Siksi ny-määrät peltohehtaaria kohti ovat olleet aiemmin niin korkeat kuin yllä esitetään. 1950-luvulla ja erikoisesti sen loppupuolella on karjaa näillä alueilla ryhdytty laiduntamaan viljellyillä laitumilla. Nyt on jäänyt talvirehujen viljelyyn peltoa vähemmän ja kotieläinten lukua on täytynyt supistaa. Kotieläinten 
tuotokset ovat kohonneet. Eläintä kohti tarvitaan nyt enemmän rehua kuin esim. 1930-luvulla. Tarkkailukarjoissa käytettiin tarkkailuvuonna 1938/39 lehmää kohti 2123 ry kotoisia rehuja, mutta vuonna $1960 / 61$ käytetty määrä oli 2710 ry (26). Kotoisten rehujen kulutus eläintä kohti on lisääntynyt 22 vuoden aikana $28 \%$.

Sekä 1940- että 1950-luvulla viljelmien kotieläinrakennusten tarvetta määritettäessä näyttää perusteena olleen lähinnä 1930- ja 1940-luvulla viljelmillä keskimäärin hehtaaria kohti pidetty kotieläinmäärä. Kun tulevan 10-20 vuoden kehitystä ei ole pystytty täysin oivaltamaan, on useassa tapauksessa päädytty siihen, että pystytetään kotieläinrakennus entisen kaavan mukaan. Koska kotieläinten ruokinta rakentamisen jälkeen ei ole pysynyt entisessä kaavassa, on jouduttu siihen, että viljelmällä ei voida pitää niin monta kotieläintä kuin navettaan mahtuisi, mikäli ruokinta perustuu kotona tuotettuihin rehuihin. Ja kun ruokinnassa on noudatettu tiukasti sitä linjaa, että sen tulee perustua melkein yksinomaan kotoisiin rehuihin, kotieläinrakennuksia joudutaan käyttämään vajaakapasiteetilla.

Myös hevosten vähentäminen on lisännyt monella viljelmällä käyttämättä jäävää rakennusalaa. Hevosesta luopumisen jälkeen on voitu lisätä muiden kotieläinten, tutkimusalueella lähinnä lehmien määrää. Hevosta kohti vapautuva rakennusala on kuitenkin suurempi kuin se rakennusala, jonka hevosen rehuilla pidettävä lehmämäärä tarvitsee.

\section{Korsirehuvarastot}

Suomalaisilta viljelmiltä myydään hyvin vähän korsirehua suoraan pellolta. Se korsirehumäärä, joka viljelmällä tuotetaan, harvoja poikkeuksia lukuunottamatta myös varastoidaan viljelmälle. Jos viljelmältä saatavan korsirehusadon määrä voidaan likimäärin arvioida, pystytään määrittämään myös varastojen tarve.

Sillä alueella, jota tutkimus koskee, peltoviljely on lähes yksinomaan rehukasvien viljelyä. Leipäviljan ja muiden kauppakasvien viljelyä voi tapahtua vain sangen rajoitetusti. Alla on esitetty tärkeimpien viljelykasvien suhteelliset alat Pohjois-Karjalan maanviljelysseuran alueella vuonna 1941, 1950 ja 1959 suoritetun maatalouslaskennan mukaan. Kesantoala ei ole laskelmassa mukana.

$\begin{array}{lrrr} & 1941 & 1950 & 1959 \\ \text { Heinä } & 62.0 \% & 58.4 \% & 59.7 \% \\ \text { Laidun } & 2.5, & 3.1, & 5.9, \\ \text { Kaura } & 13.1, & 15.3, & 14.6, \\ \text { Ohra } & 4.3, & 4.1, & 8.7, \\ \text { Ruis } & 8.7, & 6.6, & 4.5, \\ \text { Vehnä } & 5.4, & 8.0, & 2.4, \\ \text { Peruna + juurik. } & 4.0, & 4.5, & 4.2, \\ \text { Muut kasvit } & 0.0, & 0.0, & 0.0, \\ \text { Yhteensä } & 100.0, & 100.0, & 100.0,\end{array}$

Varsinaisilla rehukasveilla (heinä, laidun kaura ja ohra) on ollut vuosina 1941 noin $82 \%$, vuonna 1950 noin $81 \%$ mutta vuonna 1959 noin $89 \%$ viljelykasvien alasta. Heinää, joka korjataan tutkimusalueella lähes yksinomaan kuivaksi heinäksi, on kasvatettu noin $60 \%: 1 l a$ viljelykasveilla olleesta alasta. Oljet korjataan tällä 
alueella yleisesti talteen, koska niitä tarvitaan kuivikkeiksi. Myös rukiin ja vehnän oljet otetaan harvoja poikkeuksia lukuunottamatta varastoon.

Korsirehuvarastojen tarve on tässä laskettu sen mukaan, kuinka paljon on varastoitavaa heinää ja olkea yhteensä. Tutkituilta viljelmiltä ei ole tiedusteltu pellon käyttöä, mutta kyllä satojen suuruus. Kun sadot on tiedusteltu vuonna 1960 ja 1961, jolloin ne olivat parhaimpia, mitä maassamme on saatu, näiden tulosten perusteella ei ole laskettu viljelmän rakennustarvetta, vaan tiedusteltujen satojen ja kirjoittajan viljelyn voimaperäisyydestä saaman käsityksen mukaan viljelmät on jaettu 5 satoisuusluokkaan; heikko, tyydyttävä, keskinkertainen, hyvä ja erittäin hyvä. Satoisuusluokka keskinkertainen vastaa niitä keskisatoja, jotka on saatu Pohjois-Karjalan tilastoviljelmiltä vuosina 1956-60. Seuraavassa asetelmassa on esitetty kasvien keskimääräiset sadot Pohjois-Karjalassa (satoisuusluokka keskinkertainen) ja arvioidut sadot muissa satoisuusluokissa.

\begin{tabular}{|c|c|c|c|c|c|}
\hline \multirow[b]{2}{*}{ Kasvi } & \multicolumn{5}{|c|}{ Satoisuusluokat } \\
\hline & heikko & $\begin{array}{l}\text { tyydyt- } \\
\text { tävä }\end{array}$ & $\begin{array}{l}\text { keskin- } \\
\text { kertainen }\end{array}$ & hyvä & $\begin{array}{c}\text { erittäin } \\
\text { hyvä }\end{array}$ \\
\hline Heinä & 2000 & 2500 & 3230 & 4000 & 4800 \\
\hline Kaura & 1000 & 1200 & 1550 & 1900 & 2300 \\
\hline Ohra & 1100 & 1300 & 1640 & 2000 & 2400 \\
\hline Vehnä & 1000 & 1200 & 1500 & 1800 & 2300 \\
\hline Ruis & 1000 & 1200 & 1530 & 1800 & 2300 \\
\hline
\end{tabular}

Varastoitavaa olkea on arvioitu saatavan kaurasta, ohrasta ja vehnästä sama määrä kuin jyviä, mutta rukiista 1.5 kertaa jyväsato. Leikkuupuintia käytettäessä olkia ei saada varastoon yhtä paljon kuin vanhemmilla korjuumenetelmillä. Siksi olkisadot on arvioitu alhaisemmiksi kuin esim. Linkolan (14, s. 52) ja REINIKAISEN (21, s. 202) tutkimustulokset ja aiemmin käytetyt normiluvut edellyttävät. Viljelmän peltoalan käytön on oletettu jakaantuvan samalla tavalla, kuin paikkakunnan vastaavan suuruisilla viljelmillä kirjanpidon mukaan peltoalan käyttö on jakaantunut.

Heinää lasketaan maatalousministeriön asutusasiainosaston ohjekirjasen mukaan $(16, \mathrm{~s} .41)$ mahtuvan $55 \mathrm{~kg}$ ja olkia $45 \mathrm{~kg}$ yhteen varastokuutiometriin. SIPIL $(23$, s. 104) suosittelee käytettäväksi varastotilan tarvetta laskettaessa heinäkuutiometrin painona $70 \mathrm{~kg}$ ja olkikuutiometrin painona $50 \mathrm{~kg}$. Linkola $(13, \mathrm{~s} .27)$ on saanut tutkimuksissaan heinien painoksi $62 \mathrm{~kg} / \mathrm{m}^{3}$ ja olkien painoksi $42 \mathrm{~kg} / \mathrm{m}^{3}$. Hän on selvittänyt heinien ja olkien painon talvella, johon mennessä heinät ja oljet olivat ehtineet painua useita kuukausia. Satoa varastoon pantaessa varastoon ei voitane panna näin paljon heiniä ja olkia. Tässä tutkimuksessa kirjoittaja on laskenut yhteen latokuutiometriin mahtuvan sadonkorjuuaikana $50 \mathrm{~kg}$ heiniä ja $40 \mathrm{~kg}$ olkia.

Yllä esitetyin perustein saadaan selville viljelmän keskimääräinen korsirehuvarastojen tarve. Sadot vaihtelevat keskiarvoa molemmin puolin. Pohjois-Karjalan maanviljelysseuran alueella on maatalouden vuositilaston mukaan keskimääräinen vuotuinen heinäsato vaihdellut 9:ssä tapauksessa 10 :stä vähemmän kuin $10 \%$ vuosien 1951-1960:n keskisadosta. Yksityisissä tapauksissa satovaihtelut ovat 
huomattavasti suurempia kuin suurehkon alueen keskimääräiset satovaihtelut. Varastojen maksimitarve voi vaihtelusta johtuen silloin tällöin kohota huomattavasti keskiarvon yläpuolelle. Harvoin toistuvat suuret sadot eivät kuitenkaan saisi olla perustana varastoja suunniteltaessa, vaan ehkä jo $10 \%$ ylimitoitus olisi riittävä. Parhaimpina satovuosina voidaan heikoin, kuivikkeena käytettävä olkitavara varastoida ulos.

Taulukossa 14 on esitetty viljelmien suhteellinen jakaantuminen korsirehuvarastojen kapasiteetin hyväksikäytön mukaan. Tulokset on esitetty sekä viljelmä-

Taulukko 14. Tutkittujen viljelmien jakaantuminen viljelmåsuuruusluokittain korsirehuvarastojen kapasiteetin hyväksikäytön mukaan.

Table 14. Distribution of the farms by size class according to the utilisation of capacity of straw feed storages.

\begin{tabular}{|c|c|c|c|c|}
\hline \multirow{2}{*}{$\begin{array}{c}\text { Kapasiteetin } \\
\text { hyväksikäyttő } \\
\% \\
\text { Utilisation of } \\
\text { of capacity } \\
\%\end{array}$} & \multicolumn{4}{|c|}{$\begin{array}{c}\text { Viljelmien osuus \% luokan viljelmien luvusta } \\
\text { Farm in per cent of total farms } \\
\text { Vilielmäsunruusluokat }\end{array}$} \\
\hline & I & II & III & All farms \\
\hline $10-29$ & 5.7 & - & - & 3.1 \\
\hline $30-49$ & 16.9 & 14.0 & 12.5 & 15.5 \\
\hline $50-69$ & 26.8 & 38.0 & 25.0 & 31.0 \\
\hline $70-89$ & 21.1 & 32.0 & 25.0 & 25.6 \\
\hline $90-109$ & 15.5 & 10.0 & 12.5 & 13.2 \\
\hline $110-129$ & 4.2 & 4.0 & 25.0 & 5.4 \\
\hline $130-149$ & 4.2 & 2.0 & - & 3.1 \\
\hline $150-169$ & 1.4 & - & - & 0.8 \\
\hline $170-189$ & 1.4 & - & - & 0.8 \\
\hline $190-209$ & 2.8 & - & - & 1.5 \\
\hline $\begin{array}{l}\text { Yhteensä } \\
\text { Total }\end{array}$ & 100.0 & 100.0 & 100.0 & 100.0 \\
\hline
\end{tabular}

suuruusluokittain että yhtenä ryhmänä. Eräissä tapauksissa kapasiteetin hyväksikäyttö on ollut jopa kaksisataa. Näin ei luonnollisesti voi olla. Yhteen varastokuutiometriin ei voi mahtua $100 \mathrm{~kg}$ heiniä tai $80 \mathrm{~kg}$ olkia. Näissä tapauksissa varastoja on ollut liian vähän tarpeeseen verrattuna. Näillä viljelmillä on jo silloin, kun sato on ollut keskinkertainen, jouduttu varastoimaan osa korsirehuista tai kuivikkeista ulos. Keskimäärin korsirehuvarastojen kapasiteetista oli käytetty hyväksi I suuruusluokan viljelmillä $62 \%$ toisen suuruusluokan viljemillä $64 \%$ ja kolmannen suuruusluokan viljelmillä $74 \%$.

Viljelmistä kuuluu sangen pieni osa siihen ryhmään, jossa kapasiteetin hyväksikäyttö on 90 - 109. Pääasiallisesti kapasiteetista on käytetty hyväksi vähemmän kuin $90 \%$. Korsirehuvarastojen alhainen hyväksikäyttö johtuu monessa tapauksessa siitä, että pellot ovat useana eri palstana ja palstojen välit niin pitkät, ettei ole ollut mahdollista siirtää rehuja eri palstoilta talouskeskukseen tai toiselta palstalta toiselle sadonkorjuuaikana. Ennen 1950-lukua, jolloin kumipyöräisten ajo- 
neuvojen käyttö oli vähäistä, rakennettiin korsirehuvarastoja niin tiheään, etteivät ajomatkat muodostuneet liian pitkiksi. Näin varastoja tarvittiin lähes jokaista peltohehtaaria kohti se määrä, minkä peltohehtaarilta saadun heinäsadon arveltiin varastotilaa tarvitsevan. Nykyisin käytössä olevilla kuljetusvälineillä voidaan heinät ja oljet siirtää kesälläkin pitkiä matkoja. Uusien kotieläinrakennusten yhteyteen oli rakennettu sellaisiakin varastoja, joihin voitiin varastoida kaikki korsirehut. Kun entiset peltoladot olivat uusien varastotilojen ohella käyttökelpoisia, niitä pidetään toistaiseksi kunnossa. Tällaisesta kehityksestä on ollut seurauksena, että korsirehuvarastojen määrä viljelmillä, joille oli rakennettu uusi kotieläinrakennus korsirehuvarastoineen, oli tutkimushetkellä $2-3$ kertainen keskimääräiseen tarpeeseen verrattuna.

Viljelmillä, joilla viljelyn voimaperäisyys on ollut heikko, näyttää varastotilaa laskettuun tarpeeseen verrattuna olleen enemmän kuin voimaperäisesti viljellyillä viljelmillä. Seuraavassa asetelmassa on esitetty kapasiteetin keskimääräinen hyväksikäyttöprosentti eri satoisuusluokissa.

$\begin{array}{lcc}\text { Satoisuusluokka } & \begin{array}{c}\text { Kapasiteetin hyväksi- } \\ \text { käyttö \% }\end{array} & \text { Havaintojen luku } \\ \text { Heikko } & 67 & 5 \\ \text { Tyydyttävä } & 56 & 23 \\ \text { Keskinkertainen } & 67 & 62 \\ \text { Hyvä } & 69 & 31 \\ \text { Erittäin hyvä } & 78 & 8\end{array}$

Hajonta kussakin satoisuusluokassa on verraten suuri. Tämän vuoksi tulosta voidaan pitää lähinnä suuntaa antavana. Heikommassa satoisuusluokassa kapasiteetin hyväksikäyttö on parempi kuin seuraavassa, mutta eräillä heikoimpaan

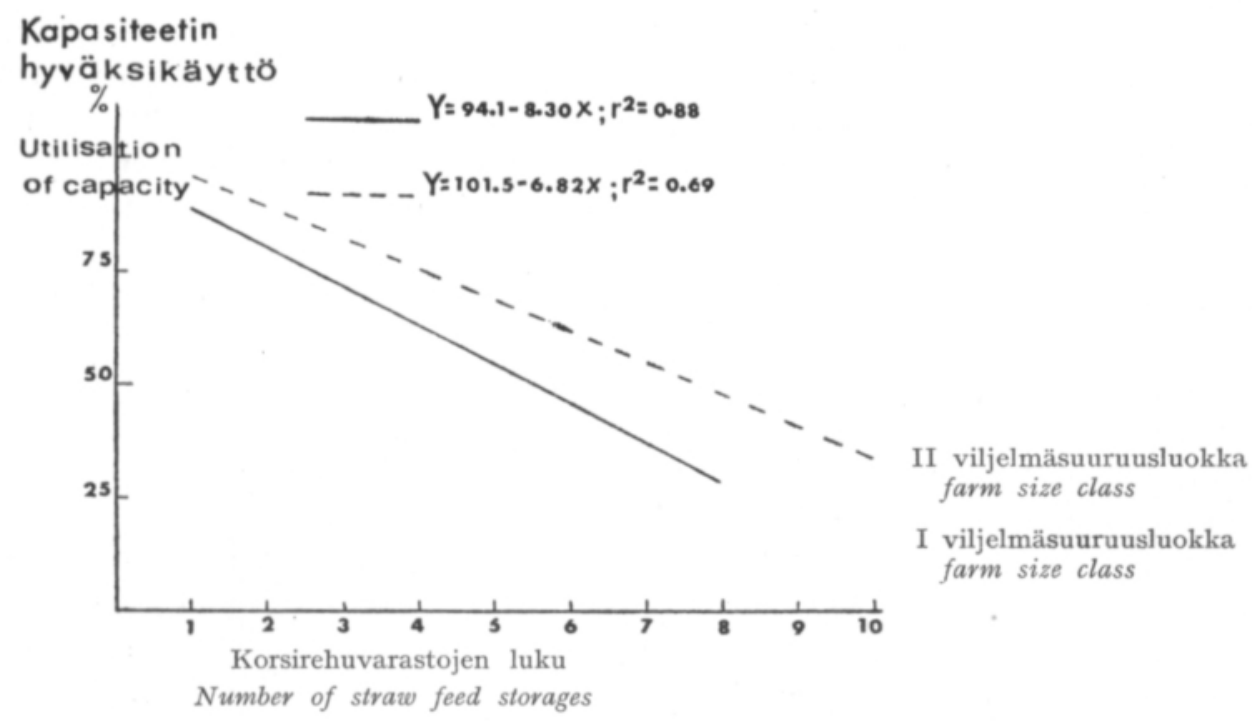

Kuvio 7. Korsirehuvarastojen kapasiteetin hyväksikäyttö varastojen luvun muuttuessa. Fig. 7. Utilisation of the capacity of the straw feed storages with the changing number of storages. 
satoisuusluokkaan kuuluvilla viljelmillä varastot olivat niin vähäiset, ettei tuloksella tämän vuoksi ole mainittavaa merkitystä.

Kuviossa 7 on esitetty tutkituilla viljelmillä olleiden varastojen luvun ja varastotilan hyväksikäytön välinen riippuvuus. Muutamia poikkeuksia lukuunottamatta kapasiteetin hyväksikäyttö heikkenee sitä mukaa, kun varastojen luku lisääntyy. Viljelmän rakennuskustannuksia hajalleen rakentaminen lisää kahdella tavalla. Ensiksi, rakennuskuutioita tarvitaan enemmän, koska hajalleen rakennettaessa kapasiteettia ei voida käyttää hyväksi niin suuressa määrin kuin keskitetysti rakennettaessa. Toiseksi, pieniä rakennuksia rakennettaessa kuutiometrin kustannus on yleensä suurempi kuin suuria rakennuksia rakennettaessa.

Muiden kuin korsirehuvarastojen kapasiteetin hyväksikäyttöä tässä yhteydessä ei voida selvittää. Tutkimusaineistoa koottaessa ei ole eritelty, mikä osa esimerkiksi aitoista on rakennettu viljan varastointia varten ja mikä osa taas muiden elintarvikkeiden tai vaatteiden säilytyspaikaksi. Pienillä viljelmillä tällaista jakoa ei aina voida laisinkaan suorittaa ja myös keskikokoisilla viljelmillä rajan määrittäminen saattaa olla vaikeaa. Peruna- ja juurikasvivarastojen kapasiteetin hyväksikäytön toteaminen tutkituilla viljelmillä on niinikään vaikeaa. Tutkimusalueella viljellään näitä kasveja noin $4 \%$ :lla koko peltoalasta. Yksityisillä viljelmillä viljelyalat vaihtelevat huomattavasti. Kun viljelyaloja ei ole tiedusteltu, tämän tutkimusaineiston puitteissa ei voida selvittää myöskään peruna- ja juurikasvivarastojen hyväksikäyttöä.

\section{Ti ivistelmä}

Käsillä olevassa tutkimuksessa on pyritty selvittämäån maatalousrakennusten määrää ja arvoa sekä eräiden rakennusten kapasiteetin hyväksikäyttöä tutkituilla viljelmillä. Tutkimusaineisto on kerätty viiden Joensuun kaupungin etelä- ja länsipuolella olevan kunnan alueelta. Tutkimuksen kohteena ovat olleet kaikki ne (129) viljelmät, jotka näiden kuntien alueella joutuivat luovuttamaan peltoa uusien valtamaanteiden rakentamiseen vuosina 1956-1961. Taulukoissa 1 ja 2 on esitetty maankäyttölajien jakaantuminen ja viljelmien keskimääräinen koko tutkimusalueella.

Eri rakennusten keskimääräinen pinta-ala ja tilavuus on esitetty taulukossa 3 ja 4. Asuinrakennusten ala henkilöä kohti oli alle 10 ha:n viljelmillä $17.6 \mathrm{~m}^{2}, 10.00$ 24.99 ha:n viljelmillä $21.3 \mathrm{~m}^{2}$ ja $25.00-49.99$ ha:n viljelmillä $28.5 \mathrm{~m}^{2}$.

Tutkittujen viljelmien kotieläinrakennusten ala peltohehtaaria kohti lisääntyy aluksi peltoalan kasvaessa (kuvio 1). Maksimin rakennusten määrä hehtaaria kohti saavuttaa noin 8 peltohehtaarin viljelmillä. Tämän jälkeen rakennusten määrä supistuu peltoalan edelleen lisääntyessä. Kun kotieläinten määrä peltohehtaaria kohti viljelmän pienentyessä lisääntyy (kuvio 2), jää pienillä viljelmillä rakennusalaa eläintä kohti vähiten. Kuviossa 3 on esitetty kotieläinrakennusten ala peltohehtaaria kohti kumulatiivisena frekvenssikäyränä. Kuviosta voidaan havaita tutkimusaineistossa tarkasteltavaan omaisuuteen nähden vallitseva suuri hajonta. Hajontaa on tarkasteltu yksityiskohtaisemmin taulukossa 5 . 
Korsirehuvarastoja oli tutkituilla viljelmillä keskimäärin runsaasti (taulukko 3 ja 4). Mitä suurempi varastojen luku oli sitä enemmän viljelmillä oli varastotilaa hehtaaria kohti. Kuviossa 4 on esitetty korsirehuvarastojen määrä viljelmäsuuruusluokittain kumulatiivisenä frekvenssikäyränä.

Eri rakennusten tai rakennusryhmien keski-ikä oli verraten alhainen (taulukko 6). Ensimmäisen suuruusluokan viljelmien rakennukset olivat keskimäärin nuorimpia. Rakennusten keski-ikä lisääntyi viljelmän peltoalan kasvaessa.

Asuin- ja varastorakennukset olivat lähes yksinomaan puisia (taulukko 7), mutta kotieläinrakennuksista oli huomattava osa kivirakenteisia.

Rakennusten arvo on laskettu viljelmäsuuruusluokittain sekä koko viljelmää että yhtä peltohehtaaria kohti (taulukot $8-11$ ). Talousrakennusten arvo peltohehtaaria kohti peltoalan funktiona on esitetty kuviossa 5. Talousrakennusten arvo hehtaaria kohti aluksi lisääntyy peltoalan lisääntyessä. Se saavuttaa maksimin noin 7 peltohehtaarin viljelmillä ja alenee tämän jälkeen lähes lineaarisesti peltoalan kasvaessa. Rakennusten keskimääräinen nykyarvo oli tutkimusvuonna $62.0 \%$ jälleenhankinta-arvosta.

Lämmintä kotieläinrakennusalaa oli alle 10.00 peltohehtaarin viljelmillä keskimäärin $12.2 \mathrm{~m}^{2} / \mathrm{ny}, 10.00-24.99$ hehtaarin viljelmillä $11.7 \mathrm{~m}^{2} /$ ny ja $25.00-49.99$ hehtaarin viljelmillä $14.1 \mathrm{~m}^{2} / \mathrm{ny}$.

Tutkittujen viljelmien kotieläinrakennusten kapasiteetin hyväksikäyttö tutkimusvuonna on esitetty taulukossa 12 ja kuviossa 6 . Kapasiteetin hyväksikäyttö on vaihdellut suuresti. Kaikista viljelmistä $30.2 \%$ käytti tutkimushetkellä hyväksi $90 \%$ tai enemmän kotieläinrakennusten lasketusta maksimikapasiteetista. Näillä viljelmillä on käytetty kotieläinrakennusalaa $6.5 \mathrm{~m}^{2} / \mathrm{ny}$, ilman karjakeittiötä ja maitohuonetta ja $8.0 \mathrm{~m}^{2} /$ ny karjakeittiön ja maitohuoneen ala mukaan luettuna. Eri ikäisten kotieläinrakennusten kapasiteetin hyväksikäyttö on esitetty taulukossa 13. Kotieläinrakennusten kapasiteetin heikko hyväksikäyttö johtunee huomattavalta osalta siitä, että viimeisen kahden vuosikymmenen kuluessa kotieläinten luku peltohehtaaria kohti on supistunut lähes $30 \%$. Niissä tapauksissa, joissa maatila oli jaettu sisarusten kesken, kantatilan taloustakennusten kapasiteetin hyväksikäyttö oli yleensä alhainen.

Korsirehuvarastojen kapasiteetin hyväksikäyttö käy ilmi taulukosta 14. Eräillä viljelmillä on ollut liian vähän korsirehuvarastoja. Näillä kapasiteetin hyväksikäyttöluku ei suinkaan kuvaa todellista käyttöä, vaan osoittaa, ettei varastoja ole ollut riittävästi. Useilla viljelmillä korsirehuvarastojen luku on ollut huomattavan suuri. Kuviossa 7 on esitetty varastojen luvun ja kapasiteetin välinen riippuvuus. Niillä viljelmillä, joilla viljelyn voimaperäisyys on ollut heikko, myös korsirehuvarastojen kapasiteetin hyväksikäyttö näyttää olleen heikompi kuin voimaperäisesti viljellyillä viljelmillä. 
(1) AnNILA, M. 1957. Maatalouden rakennusten vuosikustannuksista kirjanpitotiloilla tilivuonna 1953/54-1954/55. Teho 1957: 131-134.

(2) Arola, J. 1957. Rakennusten arvioinnista. Miten rakennan 1957, 3: 79-89.

(3) Aspiala, T. 1949. Keskittämisen vaikutus pientilojen rakennusten hankinta-, pito- ja palvelukustannuksiin sekä rakennusainemenekkiin. Valt. tekn. tutk.lait. Tied. 59.

(4) Gripenberg, O. 1945. Eräiden puisten pientalojen hankintakustannuksiin vaikuttavista tekijöistä. Sama 27: 1-10.

(5) Henriksson, R. 1954. Årskostnader för jordbrukets ekonomibyggnader. Stat. forskn. anst. för lantm. byggn. Medd. 31 .

(6) Huelm, Lennart 1956. Ekonomisk planering av driften och dess olika grenar. Landbrukets driftsekonomi s. 405-498. Stockholm.

(7) HolmQvist, N. 1953. Värdering av ekonomibyggnader och bostäder vid landbruket. Stat. forskn.anst. för lantm.byggn. 26: 1-23.

(8) Holmström, Sven 1958. Kapitalinvestering i jordbrukets byggnader. Medd. från jordbr. utredn.instit. 1958, 9: 1-92.

(9) Hybler, K. H. 1958. Die Gebäudesituation in den landwirtschaftlichen Betrieben Hessens. Diss. Inst. für landw. Betr.lehre der Justus-Liebig-Univers, Giessen.

(10) Jordbrukets byggnadskostnader avgivet av 1942 års byggnadssakunniga för landsbygden. Stat. off. uträdn. 1942: 38 .

(11) Karjarakennus ja sen suunnittelu ja rakentaminen. Navettatoimikunnan mietintö. Helsinki 1959.

(12) Kirjanpitotilojen tuloksia tilivuodelta 1960/61. Maatal. tal. tutk.lait. tied. N:o 1.

(13) LinkolA, O. 1942. Eri viljelyskasvien sadon määrän selvittely maatilalla. Koetoim.yhd. liit. julk. 17.

(14) 1942. Kokemuksia sadon arvioimisesta v. 1942. Sama. 18.

(15) Maatalouden vuositilasto $1951-1959$. S. virall. til. III: $46-52$.

(16) Mitkä ja minkä kokoiset rakennukset viljelmä tarvitsee? Maatal.min. asut.as.os. rak.toim. julk. 3.

(17) MăKı, Antri 1949. Maatalouden rakennusoloista Suomessa 1938. Metsätiet. tutkim.lait. julk. 37,5.

(18) Møller, B. K. 1955. En lokal, undersøkelse af byggevirksomheten inden for landbruket. Tidsskr. for landekønomi 1955: 77-89, 125-134 ja 189-197.

(19) Pihattojärjestelmä. Navettatoimikunnan mietintö. Helsinki 1955.

(20) Pohjois-Karjalan komitean mietintö. 379 s. + 9 liitettä. Helsinki 1958.

(21) Reinikainen, A. 1946. Sadon arvioinnista lähinnä Suomen olosuhteissa vuosien 1941 - 1945 kokemusten perusteella. Referat: Ủber die Ernteschätzung zunächst in finnischen Verhältnissen auf Grund der Erfahrungen der Jahre 1941-1945. Acta Agral. Fenn. 65: 1-284.

(22) SIPILĀ, M. 1949. Rakennukset maatilan taloudessa. Työt.seur. julk. 56: 1-75.

(23) 1960. Maatalouden rakennukset. Sama 85: 1-302.

(24) SkovgaArd, K. og Buch, L. 1954. Landbrugets bygninger. Den kgl. Veterinaer- og landbohøjskole. Afdelingen for landbruksøkonomi.

(25) Sköldenberg, P. 1960. Lantbrukets ekonomibyggnader. Lantbr. av i dag 1960, 7: 225-296.

(26) Tilastoa Suomen karjantarkkailutoiminnasta tarkkailuvuosina 1938/39 ja 1960/61. Maatal. hall. tied. 274 ja 349 .

(27) Tutkimuksia Suomen maatalouden kannattavuudesta XXVIII ja XL. Sama. 294 ja 313.

(28) Westermarck, N. 1939. Kanataloustyön taloudellisesta merkityksestä, kanatalouden työnmenekistä ja työkustannuksesta sekä niihin vaikuttavista tekijöistä. S. maatal. tiet.seur. julk. 41.

(29) Yleinen maatalouslaskenta 1950 ja 1959. S. virall. til. III: 45 ja 53. 
S U M M A R Y:

THE VOLUME AND VALUE OF AGRICULTURAL BUILDINGS AND THE UTILISATION OF THE CAPACITY OF THE BUILDINGS IN CERTAIN COMMUNES OF NORTH KARELIA IN 1960

VILJO RYYNÄNEN

Department of Agricultural Economics, University of Helsinki

The object of the study is to establish the volume and value of agricultural buildings and the utilisation of the capacity of certain buildings on the farms investigated. The material was collected from five communes south and west of the town of Joensuu. It includes all (129) the farms in these communes which relinquished field area under a compulsory purchase order for the building of new highways in 1956-1961. Tables 1 and 2 show the distribution of land use and the average arable land area of the farms in the investigation area as a whole. The farms were divided into size classes according to the arable land: size class I $2.00-9.99$ hectares of arable land; II $10.00-24.99$ hectares; III $25.00-$ 49.99 hectares.

The average areas and volumes of the buildings are shown in Tables 3 and 4 . The area of dwelling houses per person was 17.6 sq.m. in farms of I size class, 21.3 sq.m. in II class and 28.5 sq.m. in III class.

The area of the livestock buildings per hectare of arable land increases to start with the arable area increase (Fig. 1). The maximum area of buildings per hectare is on farms with c. 8 hectares of arable land. Above this figure the area of buildings per hectare decreases with the increase in the arable land. As the number of livestock grows per hectare of arable land when the size of the farms diminishes (Fig. 2), small farms have the smallest area of building per animal. This is largely because the smaller the farm the more often a boiling house, a milk cooling room and even an entrance hall are absent in the livestock buildings. Most of the buildings on smaller farms are of wood and, having a short life, approximate more closely to the building need of the farms at the time of investigation than do the stone cow sheds of larger farms. Fig. 3 shows the area of livestock buildings per hectare of arable land as a cumulative frequency curve. The pronounced deviation in the investigation material in regard to this quality is quite distinct. The deviation is considered in more detail in Table 5 .

The average volume of straw feed storages on the farms studied is large (Tables 3 and 4 ). The larger the number of storages, the more storage space per hectare there is on the farms. Fig. 4 shows the volume of straw feed storages by farm size class as a cumulative frequency curve.

The mean age of the buildings or building groups is fairly low (Table 6). The buildings on the farms of size class $I$ have the lowest mean age. The mean age of the buildings increases with the arable area of the farm.

The dwelling and storage buildings are almost exclusively of wood (Table 7), bus a considerable proportion of the livestock buildings are of stone.

The value of the buildings was calculated by farm size classes for whole farms as well as per hectare of arable land (Tables 8-11). The value of the outbuildings per hectare of arable land as a function of the arable area is given in Fig. 5. The value of these buildings per hectare grows with the increase in arable area until it reaches its maximum on farms of c. 7 hectares of arable land, when it again falls almost linearly with the increase in the arable area. The mean current value of the buildings in the year of investigation was 62 per cent of the replacement value.

In addition, the study sought to establish the utilisation of the capcity of the livestock buildings and straw feed storages. The volume or area of the buildings, the requirement of livestock buildings and straw feed supplies at the time of the investigation was likewise ascertained. The utilisation of capacity is expressed as the radio of the building requirement and the volume or area of buildings on the farms at the time of the investigation. The number of domestic animals on the farm in the year of investigation is taken into account in calculating the need of livestock buildings. It is assumes that one cow needs 6.5 sq.m. of floor space when tied up. The other domestic animals are converted into livestock units (abbreviated ny) according to the floor space needed by them. To the floor area needed by domestic animals was added the area of the boiling house, milk room and entrance hall. 
The straw feed storage requirement was calculated from the storable hay and straw harvest of the farm. The crop estimate was based on five-year means. It is assumed that a straw feed storage holds $50 \mathrm{~kg} / \mathrm{cu} . \mathrm{m}$. of dry hay and $35 \mathrm{~kg} / \mathrm{cu} . \mathrm{m}$. of straw at the time of storing.

The livestock building space averages 12.2 sq.m./ny on farms with $2.00-9.99$ hectares of arable land, 11.7 sq.m./ny on farms with $10.00-24.99$ hectares of arable land and 14.1 sq.m./ny on those with $25.00-49.99$ hectares.

The utilisation of the capacity of the livestock buildings on the farms in the year of investigation is shown in Table 12 and Fig. 6. The utilisation of the capacity varies greatly. 30.2 per cent of all the farms use 90 per cent or more of the calculated maximum capacity of the livestock buildings. The livestock buildings space utilised on these farms is $6.5 \mathrm{sq} . \mathrm{m} . / \mathrm{ny}$ if boiling house and milk room are excluded and 8.0 sq.m./ny when these are included. The utilisation of the capacity of livestock buildings of different ages is shown in Table 14. The poor utilisation of the capacity of livestock buildings is due largely to the c. 30 per cent reduction in the number of domestic animals per hectare of arable land in the course of the last two decades. In some cases the farm had been divided among the heirs and the original farm was left with outhouses too large for the needs of the farm. The utilisation of the capacity was very low in these cases.

The utilisation of straw feed storages appears in Table 14. Some farms have storages that are too small. The utilisation of the capacity on these farms is thus not illustrative of the true use. The number of straw feed storages is considerable on several farms. Fig. 7 shows the dependence between the number of storages and the utilisation of the capacity. Utilisation of the capacity of straw feed sorages seems to be poorer on farms with a low farming intensity than on intensively cultivated farms. 